\title{
Effect of aerosol precursors from gas turbine engines on the volatile sulfate aerosols and ion clusters formation in aircraft plumes
}

\author{
A. M. Starik, ${ }^{* a}$ A. M. Savel'ev, ${ }^{a}$ N. S. Titova, ${ }^{a}$ E. E. Loukhovitskaya ${ }^{a}$ and U. Schumann ${ }^{b}$ \\ a Central Institute of Aviation Motors, Scientific Research Center "Raduga", 2, \\ Aviamotornaya St, 111116 Moscow, Russia.E-mail: star@ciam.ru; \\ Fax: 7095 3620373; Tel: 70953616468 \\ ${ }^{b}$ Deutsches Zentrum für Luft- und Raumfahrt (DLR), Institute of Atmospheric Physics, \\ Oberpfaffenhofen,82230 Wessling, Germany.E-mail: Ulrich.schumann@dlr.de; \\ Fax: +49 815328 1841; Tel: +498153282520
}

Received 5th November 2003, Accepted 16th March 2004

First published as an Advance Article on the web 26th April 2004

\begin{abstract}
A comprehensive analysis of the influence of sulfate aerosol precursor gases and chemi-ions generation in the internal flow of a jet engine (gas turbine engine) on sulfate volatile aerosols and ion cluster formation in an aircraft plume is presented. The evolution of the aerosol size distribution and the chemical composition change is simulated using a previously developed quasi one-dimensional flow field model with coupled gas phase kinetics, aerosol nucleation, condensation, and coagulation processes. An increased abundance of the aerosol precursors $\mathrm{SO}_{3}, \mathrm{HSO}_{3}$, and $\mathrm{H}_{2} \mathrm{SO}_{4}$ at the nozzle exit leads to an increased number of larger volatile aerosol particles, with diameter $>5$ and $9 \mathrm{~nm}$, than previously measured in aircraft exhaust plumes. Most of the gaseous $\mathrm{H}_{2} \mathrm{SO}_{4}$ gets converted to liquid aerosol particles within about $1 \mathrm{~s}$. The generation of $\mathrm{HSO}_{4}^{-}, \mathrm{NO}_{3}{ }^{-}$, $\mathrm{NO}^{+}$, and $\mathrm{H}_{3} \mathrm{O}^{+}$ions in the combustor results in the formation of charged clusters, mostly $\mathrm{HSO}_{4}{ }^{-}\left(\mathrm{H}_{2} \mathrm{SO}_{4}\right)_{m}$, $\mathrm{NO}_{3}{ }^{-}\left(\mathrm{HNO}_{3}\right)\left(\mathrm{H}_{2} \mathrm{O}\right), \mathrm{HSO}_{4}{ }^{-}\left(\mathrm{HNO}_{3}\right)_{n}, \mathrm{H}_{3} \mathrm{O}^{+}\left(\mathrm{H}_{2} \mathrm{O}\right)_{m}, \mathrm{H}_{3} \mathrm{O}^{+}\left(\mathrm{CH}_{2} \mathrm{O}\right)\left(\mathrm{H}_{2} \mathrm{O}\right)_{n}$ in the near field plume (first few hundred meters). For typical cruise conditions of a B-747 aircraft the calculated values of ion cluster concentration at the distance from nozzle exit $L<40 \mathrm{~m}$ are around $3 \times 10^{5}-3 \times 10^{6} \mathrm{~cm}^{-3}$ for fuel sulfur content $(\mathrm{FSC} \geq 0.04 \%)$ and only $7 \times 10^{4} \mathrm{~cm}^{-3}$ for free sulfur fuel $(\mathrm{FSC}=0 \%)$.
\end{abstract}

\section{Introduction}

Particles emitted by aircraft can affect the atmosphere by increasing sulfate aerosol levels, cloudiness and atmospheric chemistry. ${ }^{1-4}$ To determine the role of aircraft emitted aerosols in changes of atmospheric processes, detailed information about size distribution, composition, type, and total amount of these aerosol particles is required. Aerosol particles observed in the plume are composed of volatile (liquid) and nonvolatile (with soot core) aerosols and ice particles. ${ }^{5-11}$ Another important type of particle observed in the aircraft plume is an ion cluster. ${ }^{12-15}$ The charged clusters may play a significant role in the formation of large volatile aerosol particles. ${ }^{16}$ Another possible mechanism of ion cluster influence on the volatile and nonvolatile particle formation is associated with ion cluster-soot interaction. Charged clusters formed in the near field plume can attach to soot particles, induce the charge on their surfaces and stimulate water or sulfuric acid uptake by the soot particles. Charged soot particles may agglomerate and form relatively large (with diameter $\sim 1 \mu \mathrm{m}$ ) submicron aerosol particles. The key questions in this problem are what kind of primary charged clusters may be abundant in a near field plume and what its concentration may be behind the nozzle exit.

Measurements have demonstrated that a large fraction of the particles was volatile, presumably containing condensed sulfuric acid. ${ }^{17-19}$ Sulfuric acid has been measured at large concentrations in aircraft plumes after evaporation of the aerosol formed in the sample taken from the engine exhaust. ${ }^{20}$ No gaseous sulfuric acid (GSA) has been detected in such measurements. ${ }^{13}$ Only an upper limit for the GSA concentration of $<2 \times 10^{8} \mathrm{~cm}^{-3}$ could be obtained with the instruments available. Any GSA initially formed seems to experience rapid gas-to-particle conversion at plume ages $<1.6 \mathrm{~s}$.

Hence an understanding of the processes that control sulfate aerosol and ion cluster formation is important for investigation of the mechanisms of aircraft particle generation. In spite of the great progress attained in understanding these mechanisms some questions remain unresolved and introduce significant uncertainty into assessments of this problem. Recent investigations have shown that the formation of volatile aerosols in aircraft plumes depends on $\mathrm{OH}, \mathrm{SO}_{2}, \mathrm{SO}_{3}, \mathrm{H}_{2} \mathrm{SO}_{4}$, and ion concentrations at the nozzle exit. ${ }^{21-23}$

The present paper extends a previous analysis of the formation of S-containing species and chemi-ions inside an aircraft jet (gas turbine) engine ${ }^{24}$ and investigates the influence of the components formed inside the engine on the concentration and size distribution of sulfate aerosol particles and ion cluster production in the near field plume of an aircraft at distances up to about $1 \mathrm{~km}$ behind the aircraft.

\section{Model description}

In order to calculate the gas dynamics and the dynamics of the non-equilibrium chemical and condensation processes in the near field plume, a quasi-one dimensional (Q1D) model was used. The model computes the plume cross-section $F$ and the area-averaged velocity, temperature and pressure as a function of distance from the engine in the plume. The model uses a procedure, which was developed by Kozlov et al. ${ }^{25}$ for turbulent wakes from engine nozzles at subsonic or low supersonic velocity. The flow field results are used to compute the photochemical and condensation processes assuming that these processes do not affect the flow. ${ }^{26,27}$ 
In order to identify the effect of $\mathrm{SO}_{3}, \mathrm{HSO}_{3}$, and $\mathrm{H}_{2} \mathrm{SO}_{4}$ produced in the internal flow of the gas turbine engine on the aerosol particles and ion cluster formation we did not take into consideration any interaction between sulfate aerosols and soot particles. For the same reason any interaction of ion clusters with volatile aerosols and possible attachment of charged clusters to sulfate aerosols and soot particles is not modeled. But we have taken into account the fact that ambient air can contain the sulfur gases, mostly $\mathrm{SO}_{2}, \mathrm{H}_{2} \mathrm{~S}, \mathrm{COS}, \mathrm{CS}, \mathrm{CS}_{2} .{ }^{28}$ So under combustion of even sulfur free hydrocarbon fuel with air the various S-containing species may be abundant at the nozzle exit.

The formation of gaseous $\mathrm{H}_{2} \mathrm{SO}_{4}$ occurs as a result of $\mathrm{SO}_{2}$ oxidation by the following mechanism: $\mathrm{SO}_{2}+\mathrm{OH}+\mathrm{M} \rightarrow$ $\mathrm{HSO}_{3}+\mathrm{M}, \mathrm{HSO}_{3}+\mathrm{O}_{2} \rightarrow \mathrm{SO}_{3}+\mathrm{HO}_{2}, \mathrm{SO}_{3}+\mathrm{H}_{2} \mathrm{O} \rightarrow \mathrm{H}_{2} \mathrm{SO}_{4}$; i.e., the variation of the concentration of $\mathrm{H}_{2} \mathrm{SO}_{4}$ affects the concentration of $\mathrm{OH}$ and $\mathrm{HO}_{2}$, which are strong oxidizers. Note that the mechanism of gaseous $\mathrm{H}_{2} \mathrm{SO}_{4}$ formation is still unknown for the conditions of hot engine exhaust gases. According to Lovejoy et al. ${ }^{29}$ and Jayne et al. ${ }^{30}$ the reaction of $\mathrm{SO}_{3}$ with $\mathrm{H}_{2} \mathrm{O}$ occurs through an intermediate step of association of $\mathrm{SO}_{3}$ and $\mathrm{H}_{2} \mathrm{O}$ to form an adduct $\mathrm{H}_{2} \mathrm{O} \cdot \mathrm{SO}_{3}$, which reacts with water vapour to produce $\mathrm{H}_{2} \mathrm{SO}_{4}$, i.e. the reaction of $\mathrm{SO}_{3}$ with $\mathrm{H}_{2} \mathrm{O}$ is of second order in the water concentration. But the rate coefficient for this process has been determined in the narrow temperature range of $250 \mathrm{~K} \leq T \leq 370 \mathrm{~K}$ only. The formation of $\mathrm{H}_{2} \mathrm{O} / \mathrm{H}_{2} \mathrm{SO}_{4}$ aerosols leads to a change in the concentrations of $\mathrm{H}_{2} \mathrm{SO}_{4}$ and other chemical components, and consequently to a variation of the rates of reactions involving these species. Therefore, the equations of chemical kinetics should be integrated simultaneously with the equations describing the formation of the condensed phase.

The kinetic scheme employed by us to describe the non-equilibrium processes in the plume includes 237 reactions involving 70 neutral species, ${ }^{26}$ namely, $\mathrm{H}_{z}, \mathrm{~N}_{z}(z=1,2), \mathrm{O}_{x}(x=1-3)$, $\mathrm{H}_{2} \mathrm{O}_{z}, \mathrm{HO}_{z}, \mathrm{NO}_{x}, \mathrm{HNO}_{y}(y=1-4), \mathrm{N}_{2} \mathrm{O}, \mathrm{N}_{2} \mathrm{O}_{5}, \mathrm{CO}_{z}, \mathrm{CH}_{q}$ $(q=3,4), \mathrm{CH}_{y} \mathrm{O}_{z}, \mathrm{HCN}, \mathrm{CN}, \mathrm{NCO}, \mathrm{CH}_{3} \mathrm{NO}_{z+1}, \mathrm{SO}_{x}$, $\mathrm{HSO}_{3}, \mathrm{H}_{2} \mathrm{SO}_{4}, \mathrm{Cl}_{z}, \mathrm{ClO}_{z}, \mathrm{CF}_{z} \mathrm{Cl}_{x}, \mathrm{CCl}_{q}, \mathrm{ClNO}_{3}, \mathrm{CH}_{z+1} \mathrm{Cl}$, $\mathrm{F}_{2}, \mathrm{ClF}, \mathrm{HCl}$, and $\mathrm{HOCl}$ and a block of reactions involving positive and negative ions, namely, $\mathrm{H}_{3} \mathrm{O}^{+}, \mathrm{NO}^{+}, \mathrm{C}_{2} \mathrm{H}_{3} \mathrm{O}^{+}$, $\mathrm{NO}_{2}{ }^{+}, \mathrm{NO}_{2}^{-}, \mathrm{NO}_{3}^{-}, \mathrm{NH}_{4}^{+}, \mathrm{CO}_{3}^{-}, \mathrm{CO}_{4}^{-}, \mathrm{SO}_{2}^{-}, \mathrm{SO}_{3}^{-}$, $\mathrm{SO}_{4}^{-}, \mathrm{HSO}_{4}^{-}$, as well as the processes of formation of ion clusters: $\mathrm{H}_{3} \mathrm{O}^{+}\left(\mathrm{H}_{2} \mathrm{O}\right)_{n}(n=1 \ldots 6), \mathrm{NO}^{+}\left(\mathrm{H}_{2} \mathrm{O}\right)_{m} \quad(m=1-3)$, $\mathrm{NO}_{3}{ }^{-}\left(\mathrm{H}_{2} \mathrm{O}\right), \quad \mathrm{NO}_{3}{ }^{-}\left(\mathrm{HNO}_{3}\right)_{n-1}, \quad \mathrm{NO}_{3}{ }^{-}\left(\mathrm{HNO}_{3}\right)\left(\mathrm{H}_{2} \mathrm{O}\right)$, $\mathrm{HSO}_{4}{ }^{-}\left(\mathrm{HNO}_{3}\right)_{m-1}, \quad \mathrm{HSO}_{4}^{-}\left(\mathrm{SO}_{3}\right), \quad \mathrm{H}_{3} \mathrm{O}^{+}\left(\mathrm{CH}_{2} \mathrm{O}\right)$, $\mathrm{H}_{3} \mathrm{O}^{+}\left(\mathrm{CH}_{2} \mathrm{O}\right)\left(\mathrm{H}_{2} \mathrm{O}\right)_{m}, \mathrm{H}_{3} \mathrm{O}^{+}\left(\mathrm{CH}_{3} \mathrm{OH}\right), \mathrm{H}_{3} \mathrm{O}^{+}\left(\mathrm{CH}_{3} \mathrm{OH}\right)\left(\mathrm{H}_{2} \mathrm{O}\right)_{m}$, and $\mathrm{HSO}_{4}{ }^{-}\left(\mathrm{H}_{2} \mathrm{SO}_{4}\right)_{m}$. The rate constants for reactions with ions were selected as explained in ref. 24. The chemical reaction mechanism of ion cluster formation comprises 49 reversible reactions with 30 ion clusters (see Table 1). The rate constants for forward reactions $K^{+}$and backward reactions $K^{-}$were taken from refs. 12,28 and $31-36$ and presented in the form $K^{+(-)}=A T^{n} \exp (E / T)$, where $E$ is the activation energy, $T$ is the gas temperature, $A$ and $n$ are the coefficients. It should be noted that our model of ion cluster formation does not take into account the processes involving conversion of $\mathrm{H}_{3} \mathrm{O}^{+}\left(\mathrm{H}_{2} \mathrm{O}\right)_{m}$ ions to $\mathrm{H}^{+} \mathrm{X}_{m}\left(\mathrm{H}_{2} \mathrm{O}\right)_{n}$ where $\mathrm{X}$ may be formaldehyde $\left(\mathrm{CH}_{2} \mathrm{O}\right)$, methanol $\left(\mathrm{CH}_{3} \mathrm{OH}\right)$, and ethane $\left(\mathrm{C}_{2} \mathrm{H}_{6}\right)$, which can be present in the engine exhaust. ${ }^{37}$ The abundance of this type of ion cluster has been observed in the exhaust of a jet fuel burner. ${ }^{38}$

In order to estimate the conceivable effect of the uncertainties in the magnitude of the rate coefficient for the reaction $\mathrm{H}_{2} \mathrm{O}+\mathrm{SO}_{3} \rightarrow \mathrm{H}_{2} \mathrm{SO}_{4}$ on the GSA concentration in the plume and consequently on the sulfate aerosol particle formation we have considered two model cases: (1) the reaction of $\mathrm{SO}_{3}$ with $\mathrm{H}_{2} \mathrm{O}$ is first order in the water vapor concentration for the total range of the plume temperatures $220 \mathrm{~K}<T<600 \mathrm{~K}$ with the corresponding rate coefficient $K^{+}=7.23 \times 10^{8} \mathrm{~cm}^{3} \mathrm{~mol}^{-1} \mathrm{~s}^{-1}$ reported in ref. 5; (2) in the temperature range $220 \mathrm{~K}<T<370 \mathrm{~K}$ this reaction is second order in $\mathrm{H}_{2} \mathrm{O}$ concentration, $N_{\mathrm{H}_{2} \mathrm{O}}$ and the first-order rate coefficient for the $\mathrm{SO}_{3}$ loss by reaction with $\mathrm{H}_{2} \mathrm{O} \mathrm{K} \mathrm{K}^{+}\left(\mathrm{s}^{-1}\right)=3.9 \times 10^{-41} \exp (6830.6 / T) N_{\mathrm{H}_{2} \mathrm{O}}{ }^{2}$ was taken from ref. 30 .

In the present study we consider a single jet plume of a B-747 aircraft with an RB211-524B engine at cruise (altitude $H=10.7 \mathrm{~km}$, Mach number $M_{0}=0.8$ ). The boundary conditions for plume modeling are provided by the parameters and gas composition at the nozzle exit and in the background atmosphere as listed in Table 2. The gas composition including S-containing species and chemi-ions at the nozzle exit was taken from calculations, as described by Starik et al. ${ }^{24}$ of temperature, pressure, and species concentration evolution in the internal flow of the engine with the Q1D model of Savel'ev et $a .^{39}$ for three different values of fuel sulfur content ( $\mathrm{FSC}=0 \% ; 0.04 \%$ and $0.3 \%$ per mass). Additionally we have considered the case when nonmethane hydrocarbons, mostly $\mathrm{CH}_{2} \mathrm{O}$, may be abundant at the nozzle exit. In accordance with the analysis performed by $\mathrm{Yu}$ et al. ${ }^{37}$ we have assumed a $\mathrm{CH}_{2} \mathrm{O}$ emission index of $23 \mathrm{mg} \mathrm{kg}^{-1}\left(\mathrm{CH}_{2} \mathrm{O}\right.$ concentrations for this case are listed in Table 2 in the line with $\mathrm{CH}_{2} \mathrm{O}$ in brackets). The background atmospheric composition was taken from refs. 27 and 28

A prerequisite for successful modeling of the aerosols in the plume is the correct modeling of plume mixing. Fig. 1 shows the computed evolution of plume radius, $R$, temperature, $T$, and the related decrease of the normalized excess in temperature, $\Delta T$, and in carbon dioxide mole fraction, $\Delta \mathrm{CO}_{2}$, above ambient air along the plume axis. From measured dilution data $^{40}$ one expects a decrease of $\Delta T$ and $\Delta \mathrm{CO}_{2}$ with plume age $t$ according to:

$$
\Delta T=(1-\eta) Q /\left(c_{p} N(t)\right) \text {, and } \Delta \mathrm{CO}_{2}=\mathrm{EI}_{\mathrm{CO}_{2}}(29 / 44) / N(t) \text {, }
$$

where $N(t)=7000\left(t / t_{0}\right)^{0.8}$ is the interpolated dilution factor measuring the mass of exhaust gases per unit mass of fuel burned, $t_{0}=1 \mathrm{~s}$ is a reference time, $\eta \approx 0.3$ is the overall propulsion efficiency of modern engines, $Q=43 \mathrm{MJ} \mathrm{kg}^{-1}$ is the combustion heat of kerosene, $c_{p}=1004 \mathrm{~J} \mathrm{~kg}^{-1} \mathrm{~K}^{-1}$ is the specific heat capacity of the exhaust gases mixed with air at constant pressure, $\mathrm{EI}_{\mathrm{CO}_{2}}=3.15$ is the emission index for carbon dioxide per unit mass of burned kerosene, and 29/44 is the ratio of molar masses of air and $\mathrm{CO}_{2}$. The interpolation curves are best applicable for plume ages $t$ of $0.3 \mathrm{~s}<t<10^{4} \mathrm{~s}$. Therefore, the plume values are plotted normalized with $\Delta T_{0}=(1-\eta) Q / c_{p}$ and $\left[\Delta \mathrm{CO}_{2}\right]_{0}=\mathrm{EI}_{\mathrm{CO}_{2}}(29 / 44)$. The normalized value of $\Delta T$ at early plume ages is larger than that of the normalized $\Delta \mathrm{CO}_{2}$ since part of the heat leaves the engine in the form of kinetic energy and it takes turbulent mixing and dissipation to convert the kinetic energy into internal energy of the exhaust. For $t=4 \mathrm{~s}$, the empirical dilution law implies $\Delta T=1.4 \mathrm{~K}$ and $\Delta \mathrm{CO}_{2}=10^{-4}$. The model computes $\Delta T=1.8 \mathrm{~K}$ and $\Delta \mathrm{CO}_{2}=3.7 \times 10^{-5}$, which shows that the model computes plume dilution in reasonable agreement with observations.

The condensation growth of sulfate aerosol droplets has been computed using Euler's method of fractions. In this method the entire spectrum of droplets is divided into $\Gamma$ separate fractions (numbered with $\gamma=1 \ldots \Gamma$ ) so that the radius $r$ of a droplet of the $\gamma$-th fraction satisfies the conditions $r_{\gamma}<r<r_{\gamma+1}$. Within the Q1D approach the equations of conservation of mass of the $i$-th gaseous component of the mixture and the mass of the $\gamma$-th fraction of droplets may be represented in the form:

$$
\begin{gathered}
\frac{\mathrm{d}}{\mathrm{d} x}\left(\rho_{i} u F\right)=\frac{\mathrm{d}}{\mathrm{d} x}\left(\rho_{i \infty} u F\right)+F m_{i}\left(G_{i}-J_{c i}\right), \\
\frac{\mathrm{d}}{\mathrm{d} x}\left(\rho_{\gamma} u F\right)=\frac{\mathrm{d}}{\mathrm{d} x}\left(\rho_{\gamma \infty} u F\right)+F \psi_{\gamma}, \\
\psi_{\gamma}=\chi_{0} \delta_{1 \gamma}+\chi_{\gamma}+\omega_{\gamma}
\end{gathered}
$$


$K^{+} /\left(\mathrm{cm}^{3} \mathrm{~mol}^{-1}\right)^{m} \mathrm{~s}^{-1}$

\begin{tabular}{|c|c|c|c|c|c|c|c|}
\hline \multirow[b]{2}{*}{ No. } & \multirow[b]{2}{*}{ Reaction } & & & & \\
\hline & & $A$ & $n$ & $E$ & $A$ & $n$ & E \\
\hline $1^{b}$ & $\mathrm{H}_{3} \mathrm{O}^{+}+\mathrm{H}_{2} \mathrm{O}+\mathrm{M}=\mathrm{H}_{3} \mathrm{O}^{+}\left(\mathrm{H}_{2} \mathrm{O}\right)+\mathrm{M}$ & $1.8(21)$ & 0 & 0 & $3.77(10)$ & -5 & -15910 \\
\hline $2^{b}$ & $\mathrm{H}_{3} \mathrm{O}^{+}\left(\mathrm{H}_{2} \mathrm{O}\right)+\mathrm{NO}_{2}^{-}=\mathrm{H}+2 \mathrm{H}_{2} \mathrm{O}+\mathrm{NO}_{2}$ & $1.2(17)$ & 0 & 0 & 0 & 0 & 0 \\
\hline $3^{b}$ & $\mathrm{H}_{3} \mathrm{O}^{+}\left(\mathrm{H}_{2} \mathrm{O}\right)+\mathrm{NO}_{3}^{-}=\mathrm{H}+2 \mathrm{H}_{2} \mathrm{O}+\mathrm{NO}_{3}$ & $1.2(17)$ & 0 & 0 & 0 & 0 & 0 \\
\hline $4^{c}$ & $\mathrm{H}_{3} \mathrm{O}^{+}\left(\mathrm{H}_{2} \mathrm{O}\right)+\mathrm{H}_{2} \mathrm{O}+\mathrm{M}=\mathrm{H}_{3} \mathrm{O}^{+}\left(\mathrm{H}_{2} \mathrm{O}\right)_{2}+\mathrm{M}$ & $8(39)$ & -7.5 & 0 & $6.86(42)$ & -8.5 & -9819 \\
\hline $5^{d}$ & $\mathrm{H}_{3} \mathrm{O}^{+}\left(\mathrm{H}_{2} \mathrm{O}\right)+\mathrm{CH}_{3} \mathrm{CHO}=\mathrm{H}_{3} \mathrm{O}^{+}\left(\mathrm{CH}_{3} \mathrm{CHO}\right)+\mathrm{H}_{2} \mathrm{O}$ & $2.1(15)$ & 0 & 0 & 0 & 0 & 0 \\
\hline $6^{d}$ & $\mathrm{H}_{3} \mathrm{O}^{+}\left(\mathrm{H}_{2} \mathrm{O}\right)+\mathrm{CH}_{2} \mathrm{O}=\mathrm{H}_{3} \mathrm{O}^{+}\left(\mathrm{CH}_{2} \mathrm{O}\right)+\mathrm{H}_{2} \mathrm{O}$ & $1.39(15)$ & 0 & 0 & 0 & 0 & 0 \\
\hline $7^{d}$ & $\mathrm{H}_{3} \mathrm{O}^{+}\left(\mathrm{H}_{2} \mathrm{O}\right)_{2}+\mathrm{CH}_{2} \mathrm{O}=\mathrm{H}_{3} \mathrm{O}^{+}\left(\mathrm{CH}_{2} \mathrm{O}\right)\left(\mathrm{H}_{2} \mathrm{O}\right)_{2}$ & $6.62(14)$ & 0 & 0 & 0 & 0 & 0 \\
\hline $8^{d}$ & $\mathrm{H}_{3} \mathrm{O}^{+}\left(\mathrm{H}_{2} \mathrm{O}\right)_{2}+\mathrm{CH}_{2} \mathrm{O}=\mathrm{H}_{3} \mathrm{O}^{+}\left(\mathrm{CH}_{2} \mathrm{O}\right)\left(\mathrm{H}_{2} \mathrm{O}\right)+\mathrm{H}_{2} \mathrm{O}$ & $6.62(14)$ & 0 & 0 & $1.93(14)$ & 0 & 387 \\
\hline $9^{d}$ & $\mathrm{H}_{3} \mathrm{O}^{+}\left(\mathrm{H}_{2} \mathrm{O}\right)_{2}+\mathrm{CH}_{3} \mathrm{CHO}=\mathrm{H}_{3} \mathrm{O}^{+}\left(\mathrm{CH}_{3} \mathrm{CHO}\right)\left(\mathrm{H}_{2} \mathrm{O}\right)+\mathrm{H}_{2} \mathrm{O}$ & $1.87(15)$ & 0 & 0 & 0 & 0 & 0 \\
\hline $10^{c}$ & $\mathrm{H}_{3} \mathrm{O}^{+}\left(\mathrm{H}_{2} \mathrm{O}\right)_{2}+\mathrm{H}_{2} \mathrm{O}+\mathrm{M}=\mathrm{H}_{3} \mathrm{O}^{+}\left(\mathrm{H}_{2} \mathrm{O}\right)_{3}+\mathrm{M}$ & $1.015(41)$ & -8.1 & 0 & $2.047(45)$ & -9.1 & -9013 \\
\hline $11^{d}$ & $\mathrm{H}_{3} \mathrm{O}^{+}\left(\mathrm{H}_{2} \mathrm{O}\right)_{3}+\mathrm{CH}_{2} \mathrm{O}=\mathrm{H}_{3} \mathrm{O}^{+}\left(\mathrm{CH}_{2} \mathrm{O}\right)\left(\mathrm{H}_{2} \mathrm{O}\right)_{2}+\mathrm{H}_{2} \mathrm{O}$ & $8.43(14)$ & 0 & 0 & 0 & 0 & 0 \\
\hline $12^{d}$ & $\mathrm{H}_{3} \mathrm{O}^{+}\left(\mathrm{H}_{2} \mathrm{O}\right)_{3}+\mathrm{CH}_{2} \mathrm{O}=\mathrm{H}_{3} \mathrm{O}^{+}\left(\mathrm{CH}_{2} \mathrm{O}\right)\left(\mathrm{H}_{2} \mathrm{O}\right)_{3}$ & $8.43(14)$ & 0 & 0 & 0 & 0 & 0 \\
\hline $13^{d}$ & $\mathrm{H}_{3} \mathrm{O}^{+}\left(\mathrm{H}_{2} \mathrm{O}\right)_{3}+\mathrm{CH}_{3} \mathrm{CHO}=\mathrm{H}_{3} \mathrm{O}^{+}\left(\mathrm{CH}_{3} \mathrm{CHO}\right)\left(\mathrm{H}_{2} \mathrm{O}\right)_{2}+\mathrm{H}_{2} \mathrm{O}$ & $1.75(15)$ & 0 & 0 & 0 & 0 & 0 \\
\hline $14^{c}$ & $\mathrm{H}_{3} \mathrm{O}^{+}\left(\mathrm{H}_{2} \mathrm{O}\right)_{3}+\mathrm{H}_{2} \mathrm{O}+\mathrm{M}=\mathrm{H}_{3} \mathrm{O}^{+}\left(\mathrm{H}_{2} \mathrm{O}\right)_{4}+\mathrm{M}$ & $5.5(54)$ & -14 & 0 & $9.03(57)$ & -15 & -6394 \\
\hline $15^{c}$ & $\mathrm{H}_{3} \mathrm{O}^{+}\left(\mathrm{H}_{2} \mathrm{O}\right)_{4}+\mathrm{H}_{2} \mathrm{O}+\mathrm{M}=\mathrm{H}_{3} \mathrm{O}^{+}\left(\mathrm{H}_{2} \mathrm{O}\right)_{5}+\mathrm{M}$ & $3.63(16)$ & 0 & 0 & $1.63(9)$ & 0 & 0 \\
\hline $16^{c}$ & $\mathrm{H}_{3} \mathrm{O}^{+}\left(\mathrm{H}_{2} \mathrm{O}\right)_{5}+\mathrm{H}_{2} \mathrm{O}+\mathrm{M}=\mathrm{H}_{3} \mathrm{O}^{+}\left(\mathrm{H}_{2} \mathrm{O}\right)_{6}+\mathrm{M}$ & $3.63(16)$ & 0 & 0 & $1.08(10)$ & 0 & 0 \\
\hline $17^{e}$ & $\mathrm{NO}_{3}^{-}+\mathrm{NO}^{+}\left(\mathrm{H}_{2} \mathrm{O}\right)=\mathrm{NO}_{3}+\mathrm{NO}+\mathrm{H}_{2} \mathrm{O}$ & $6.02(16)$ & 0 & 0 & 0 & 0 & 0 \\
\hline $18^{i}$ & $\begin{array}{l}\mathrm{NO}_{3}{ }^{-}\left(\mathrm{HNO}_{3}\right)_{n}+\mathrm{H}_{3} \mathrm{O}^{+}\left(\mathrm{H}_{2} \mathrm{O}\right)_{m}+\mathrm{M}=(\mathrm{n}+1) \mathrm{HNO}_{3} \\
\quad+(m+1) \mathrm{H}_{2} \mathrm{O}+\mathrm{M} ; n=0-5, m=1-6\end{array}$ & $1.12(29)$ & -2.5 & 0 & 0 & 0 & 0 \\
\hline $19^{i}$ & $\begin{array}{l}\mathrm{NO}_{3}{ }^{-}\left(\mathrm{HNO}_{3}\right)_{n}+\mathrm{NO}^{+}\left(\mathrm{H}_{2} \mathrm{O}\right)_{m}+\mathrm{M}=\mathrm{NO}_{3}+\mathrm{NO} \\
\quad+n\left(\mathrm{HNO}_{3}\right)+m\left(\mathrm{H}_{2} \mathrm{O}\right)+\mathrm{M} ; n=0-5, m=1-3\end{array}$ & $1.12(29)$ & -2.5 & 0 & 0 & 0 & 0 \\
\hline $20^{f}$ & $\mathrm{NO}_{3}^{-}\left(\mathrm{H}_{2} \mathrm{O}\right)+\mathrm{H}_{2} \mathrm{SO}_{4}=\mathrm{HSO}_{4}^{-}\left(\mathrm{H}_{2} \mathrm{O}\right)+\mathrm{HNO}_{3}$ & $1.236(15)$ & 0 & 0 & 0 & 0 & 0 \\
\hline $21^{g}$ & $\mathrm{NO}_{3}^{-}+\mathrm{H}_{2} \mathrm{O}+\mathrm{M}=\mathrm{NO}_{3}^{-}\left(\mathrm{H}_{2} \mathrm{O}\right)+\mathrm{M}$ & $5.76(19)$ & 0 & 0 & $2.16(10)$ & 0 & 0 \\
\hline $22^{g}$ & $\mathrm{NO}_{3}^{-}+\mathrm{HNO}_{3}+\mathrm{M}=\mathrm{NO}_{3}^{-}\left(\mathrm{HNO}_{3}\right)+\mathrm{M}$ & $3.60(21)$ & 0 & 0 & $1.07(24)$ & -1 & -13130 \\
\hline $23^{g}$ & $\mathrm{NO}_{3}^{-}\left(\mathrm{H}_{2} \mathrm{O}\right)+\mathrm{HNO}_{3}=\mathrm{NO}_{3}{ }^{-}\left(\mathrm{HNO}_{3}\right)+\mathrm{H}_{2} \mathrm{O}$ & $1.80(15)$ & 0 & 0 & $3.00(9)$ & 0 & 0 \\
\hline $24^{g}$ & $\mathrm{NO}_{3}^{-}\left(\mathrm{HNO}_{3}\right)+\mathrm{H}_{2} \mathrm{O}+\mathrm{M}=\mathrm{NO}_{3}^{-}\left(\mathrm{HNO}_{3}\right)\left(\mathrm{H}_{2} \mathrm{O}\right)+\mathrm{M}$ & $1.08(20)$ & 0 & 0 & $3.60(9)$ & 0 & 0 \\
\hline $25^{c}$ & $\mathrm{NO}_{3}^{-}\left(\mathrm{HNO}_{3}\right)+\mathrm{HNO}_{3}+\mathrm{M}=\mathrm{NO}_{3}^{-}\left(\mathrm{HNO}_{3}\right)_{2}+\mathrm{M}$ & $3.60(21)$ & 0 & 0 & $3.10(24)$ & -1 & -9240 \\
\hline $26^{g}$ & $\mathrm{NO}_{3}{ }^{-}\left(\mathrm{HNO}_{3}\right)\left(\mathrm{H}_{2} \mathrm{O}\right)+\mathrm{HNO}_{3}=\mathrm{NO}_{3}^{-}\left(\mathrm{HNO}_{3}\right)_{2}+\mathrm{H}_{2} \mathrm{O}$ & $6.00(14)$ & 0 & 0 & $3.00(9)$ & 0 & 0 \\
\hline $27^{c}$ & $\mathrm{NO}_{3}^{-}\left(\mathrm{HNO}_{3}\right)_{2}+\mathrm{HNO}_{3}+\mathrm{M}=\mathrm{NO}_{3}^{-}\left(\mathrm{HNO}_{3}\right)_{3}+\mathrm{M}$ & $3.60(21)$ & 0 & 0 & $9.60(25)$ & -1 & -7070 \\
\hline $28^{c}$ & $\mathrm{NO}_{3}{ }^{-}\left(\mathrm{HNO}_{3}\right)_{3}+\mathrm{HNO}_{3}+\mathrm{M}=\mathrm{NO}_{3}^{-}\left(\mathrm{HNO}_{3}\right)_{4}+\mathrm{M}$ & $3.6(21)$ & 0 & 0 & $1.02(24)$ & -1 & -4696 \\
\hline $29^{c}$ & $\mathrm{NO}_{3}^{-}\left(\mathrm{HNO}_{3}\right)_{4}+\mathrm{HNO}_{3}+\mathrm{M}=\mathrm{NO}_{3}^{-}\left(\mathrm{HNO}_{3}\right)_{5}+\mathrm{M}$ & $3.6(21)$ & 0 & 0 & $6.62(15)$ & 0 & 0 \\
\hline $30^{g}$ & $\mathrm{HSO}_{4}^{-}+\mathrm{HNO}_{3}+\mathrm{M}=\mathrm{HSO}_{4}^{-}\left(\mathrm{HNO}_{3}\right)+\mathrm{M}$ & $7.20(21)$ & 0 & 0 & $6.00(2)$ & 0 & 0 \\
\hline $31^{g}$ & $\mathrm{HSO}_{4}^{-}+\mathrm{H}_{2} \mathrm{SO}_{4}+\mathrm{M}=\mathrm{HSO}_{4}^{-}\left(\mathrm{H}_{2} \mathrm{SO}_{4}\right)+\mathrm{M}$ & $1.08(22)$ & 0 & 0 & $6.00(2)$ & 0 & 0 \\
\hline $32^{g}$ & $\mathrm{HSO}_{4}^{-}\left(\mathrm{HNO}_{3}\right)+\mathrm{HNO}_{3}+\mathrm{M}=\mathrm{HSO}_{4}^{-}\left(\mathrm{HNO}_{3}\right)_{2}+\mathrm{M}$ & $3.60(21)$ & 0 & 0 & $3.00(6)$ & 0 & 0 \\
\hline $33^{g}$ & $\mathrm{HSO}_{4}^{-}\left(\mathrm{HNO}_{3}\right)+\mathrm{H}_{2} \mathrm{SO}_{4}=\mathrm{HSO}_{4}^{-}\left(\mathrm{H}_{2} \mathrm{SO}_{4}\right)+\mathrm{HNO}_{3}$ & $3.00(14)$ & 0 & 0 & 0 & 0 & 0 \\
\hline $34^{g}$ & $\mathrm{HSO}_{4}^{-}\left(\mathrm{H}_{2} \mathrm{SO}_{4}\right)+\mathrm{H}_{2} \mathrm{SO}_{4}+\mathrm{M}=\mathrm{HSO}_{4}^{-}\left(\mathrm{H}_{2} \mathrm{SO}_{4}\right)_{2}+\mathrm{M}$ & $3.60(21)$ & 0 & 0 & $1.80(4)$ & 0 & 0 \\
\hline $35^{g}$ & $\mathrm{HSO}_{4}^{-}\left(\mathrm{H}_{2} \mathrm{SO}_{4}\right)_{2}+\mathrm{H}_{2} \mathrm{SO}_{4}+\mathrm{M}=\mathrm{HSO}_{4}^{-}\left(\mathrm{H}_{2} \mathrm{SO}_{4}\right)_{3}+\mathrm{M}$ & $3.60(21)$ & 0 & 0 & $4.20(3)$ & 0 & 0 \\
\hline $36^{h}$ & $\mathrm{HSO}_{4}^{-} \cdot \mathrm{HNO}_{3}+\mathrm{SO}_{3}=\mathrm{HSO}_{4}^{-} \cdot \mathrm{SO}_{3}+\mathrm{HNO}_{3}$ & $3.00(14)$ & 0 & 0 & 0 & 0 & 0 \\
\hline $37^{h}$ & $\mathrm{HSO}_{4}^{-}\left(\mathrm{SO}_{3}\right)+\mathrm{H}_{2} \mathrm{SO}_{4}=\mathrm{HSO}_{4}^{-}\left(\mathrm{H}_{2} \mathrm{SO}_{4}\right)+\mathrm{SO}_{3}$ & $3.00(14)$ & 0 & 0 & 0 & 0 & 0 \\
\hline $38^{i}$ & $\begin{array}{l}\mathrm{HSO}_{4}^{-}\left(\mathrm{HNO}_{3}\right)_{n}+\mathrm{H}_{3} \mathrm{O}^{+}\left(\mathrm{H}_{2} \mathrm{O}\right)_{m}+\mathrm{M}=\mathrm{H}_{2} \mathrm{SO}_{4}+(m+1) \mathrm{H}_{2} \mathrm{O} \\
\quad+n\left(\mathrm{HNO}_{3}\right)+\mathrm{M} ; n=1,2 ; m=0-6\end{array}$ & $1.12(29)$ & -2.5 & 0 & 0 & 0 & 0 \\
\hline $39^{i}$ & $\begin{array}{l}\mathrm{HSO}_{4}^{-}\left(\mathrm{HNO}_{3}\right)_{n}+\mathrm{NO}^{+}\left(\mathrm{H}_{2} \mathrm{O}\right)_{m}+\mathrm{M}=\mathrm{NO}_{2}+\mathrm{HSO}_{3} \\
\quad+n\left(\mathrm{HNO}_{3}\right)+m\left(\mathrm{H}_{2} \mathrm{O}\right)+\mathrm{M} ; n=1-2, m=0-3\end{array}$ & $1.12(29)$ & -2.5 & 0 & 0 & 0 & 0 \\
\hline $40^{i}$ & $\begin{array}{l}\mathrm{HSO}_{4}^{-}\left(\mathrm{H}_{2} \mathrm{SO}_{4}\right)_{n}+\mathrm{NO}^{+}\left(\mathrm{H}_{2} \mathrm{O}\right)_{m}+\mathrm{M}=\mathrm{NO}_{2}+\mathrm{HSO}_{3} \\
\quad+n\left(\mathrm{H}_{2} \mathrm{SO}_{4}\right)+m\left(\mathrm{H}_{2} \mathrm{O}\right)+\mathrm{M} ; n=0-3, m=0-3\end{array}$ & $1.12(29)$ & -2.5 & 0 & 0 & 0 & 0 \\
\hline $41^{i}$ & $\begin{array}{l}\mathrm{HSO}_{4}^{-}\left(\mathrm{H}_{2} \mathrm{SO}_{4}\right)_{n}+\mathrm{H}_{3} \mathrm{O}^{+}(\mathrm{H} 2 \mathrm{O})_{m}+\mathrm{M}=(n+1) \mathrm{H}_{2} \mathrm{SO}_{4} \\
\quad+(m+1) \mathrm{H}_{2} \mathrm{O}+\mathrm{M} ; n=1-3, m=0-6\end{array}$ & $1.12(29)$ & -2.5 & 0 & 0 & 0 & 0 \\
\hline $42^{g}$ & $\mathrm{NO}_{3}^{-} \cdot \mathrm{HNO}_{3}+\mathrm{H}_{2} \mathrm{SO}_{4}=\mathrm{HSO}_{4}^{-} \cdot \mathrm{HNO}_{3}+\mathrm{HNO}_{3}$ & $1.38(15)$ & 0 & 0 & 0 & 0 & 0 \\
\hline $43^{g}$ & $\mathrm{NO}_{3}^{-}\left(\mathrm{HNO}_{3}\right)_{2}+\mathrm{H}_{2} \mathrm{SO}_{4}=\mathrm{HSO}_{4}^{-}\left(\mathrm{HNO}_{3}\right)_{2}+\mathrm{HNO}_{3}$ & $6.60(14)$ & 0 & 0 & 0 & 0 & 0 \\
\hline $44^{b}$ & $\mathrm{NO}^{+}+\mathrm{H}_{2} \mathrm{O}+\mathrm{M}=\mathrm{NO}^{+}\left(\mathrm{H}_{2} \mathrm{O}\right)+\mathrm{M}$ & $5.76(19)$ & 0 & 0 & 0 & 0 & 0 \\
\hline $45^{b}$ & $\mathrm{NO}^{+}\left(\mathrm{H}_{2} \mathrm{O}\right)+\mathrm{H}_{2} \mathrm{O}+\mathrm{M}=\mathrm{NO}^{+}\left(\mathrm{H}_{2} \mathrm{O}\right)_{2}+\mathrm{M}$ & $3.60(20)$ & 0 & 0 & $7.80(11)$ & 0 & 0 \\
\hline $46^{b}$ & $\mathrm{NO}^{+}\left(\mathrm{H}_{2} \mathrm{O}\right)_{2}+\mathrm{H}_{2} \mathrm{O}+\mathrm{M}=\mathrm{NO}^{+}\left(\mathrm{H}_{2} \mathrm{O}\right)_{3}+\mathrm{M}$ & $3.60(20)$ & 0 & 0 & $7.80(11)$ & 0 & 0 \\
\hline $47^{b}$ & $\mathrm{NO}^{+}\left(\mathrm{H}_{2} \mathrm{O}\right)_{3}+\mathrm{H}_{2} \mathrm{O}=\mathrm{H}_{3} \mathrm{O}^{+}\left(\mathrm{H}_{2} \mathrm{O}\right)_{2}+\mathrm{HNO}_{2}$ & $4.80(13)$ & 0 & 0 & 0 & 0 & 0 \\
\hline $48^{b}$ & $\mathrm{NO}^{+}\left(\mathrm{H}_{2} \mathrm{O}\right)_{2}+\mathrm{e}=\mathrm{NO}+2 \mathrm{H}_{2} \mathrm{O}$ & $1.20(19)$ & 0 & 0 & 0 & 0 & 0 \\
\hline $49^{e}$ & $\mathrm{NO}^{+}\left(\mathrm{H}_{2} \mathrm{O}\right)+\mathrm{A}^{-}=\mathrm{NO}+\mathrm{H}_{2} \mathrm{O}+\mathrm{A} ; \mathrm{A}=\mathrm{O}_{2}, \mathrm{O}$ & $6.02(16)$ & 0 & 0 & 0 & 0 & 0 \\
\hline
\end{tabular}

${ }^{a} B(q)$ corresponds to $B \times 10^{q} .{ }^{b}$ Rate constants for reactions No. (1), (2), (3), (44)-(48) were taken from ref. 31. ${ }^{c}$ For reactions No. (4), (10), (14)-(16), (25), (27)-(29) from ref. 28..$^{d}$ For reactions No. (5)-(9), (11)-(13) from ref. 35. ${ }^{e}$ For reactions No. (17), (49) from ref. $33 f^{f}$ For reaction No. 20 from ref. 34. ${ }^{g}$ For reactions No. (21)-(24), (26), (30)-(35), (42), (43) from ref. 32. ${ }^{h}$ For reactions No. (36), (37) from ref. 12. ${ }^{i}$ For reactions No. (18), (19), (38)-(41) the rate constants were estimated on the base of formulas presented in ref. 36.

Here, $F=\pi R^{2}$ is the plume cross-section area, $m_{i}$ is the mass of molecules (atoms) of the $i$-th component; $\rho_{i}$ and $\rho_{\gamma}$ are the plume area-averaged partial density of the $i$-th component and of the $\gamma$-th fraction correspondingly; $\rho_{i \infty}$ and $\rho_{\gamma_{\infty}}$ are the constant partial densities of the $i$-th component and $\gamma$-th fraction at the plume boundary (in the atmosphere); $G_{i}$ characterizes the rate of evolution of $\rho_{i}$ due to chemical reactions; $J_{c i}$ characterizes the combined rate of transformation of $i$-th component to the condensed phase due to homogeneous nucleation and heterogeneous condensation; $\chi_{0}, \chi_{\gamma}$, 
Table 2 Summary of the initial gas-phase mole fractions and physical parameters at nozzle exit for the engine core exit, bypass exit and in the ambient air of a B-747 aircraft $\left(H=10.7 \mathrm{~km}\right.$ altitude and $M_{\infty}=0.8$ speed $)$ with $\mathrm{RB} 211-524 \mathrm{~B}$ engines $^{a}$

\begin{tabular}{|c|c|c|c|c|}
\hline Parameter/species & Engine core & & & Bypass/ambient air \\
\hline$T / \mathrm{K}$ & 598 & & & $253.4 / 219.2$ \\
\hline$P / \mathrm{Pa}$ & 23930 & & & 23930 \\
\hline Radius/m & 0.438 & & & 0.875 \\
\hline Stream velocity $/ \mathrm{m} \mathrm{s}^{-1}$ & 475.7 & & & 316.3 \\
\hline Gas composition & $\mathrm{FSC}=0 \%$ & $\mathrm{FSC}=0.04 \%$ & $\mathrm{FSC}=0.3 \%$ & \\
\hline $\mathrm{O}$ & $2.85(-8)$ & $6.58(-8)$ & $4.47(-8)$ & $1.664(-15)$ \\
\hline $\mathrm{O}_{2}$ & $1.54(-1)$ & $1.54(-1)$ & $1.54(-1)$ & $2.002(-1)$ \\
\hline $\mathrm{O}_{3}$ & $2.30(-8)$ & $5.65(-8)$ & $9.18(-8)$ & $7.275(-8)$ \\
\hline $\mathrm{H}$ & $1.23(-14)$ & $4.63(-14)$ & $3.1(-14)$ & $2.35(-20)$ \\
\hline $\mathrm{H}_{2}$ & $3.09(-8)$ & $2.15(-8)$ & $2.15(-8)$ & $9.378(-7)$ \\
\hline $\mathrm{OH}$ & $2.01(-6)$ & $2.22(-6)$ & $1.71(-6)$ & $1.071(-13)$ \\
\hline $\mathrm{HO}_{2}$ & $5.71(-10)$ & $5.66(-9)$ & $3.19(-8)$ & $1.406(-11)$ \\
\hline $\mathrm{H}_{2} \mathrm{O}$ & $4.00(-2)$ & $3.99(-2)$ & $3.99(-2)$ & $5.768(-5)$ \\
\hline $\mathrm{H}_{2} \mathrm{O}_{2}$ & $2.17(-7)$ & 0 & $2.76(-7)$ & $8.79(-10)$ \\
\hline $\mathrm{N}_{2}$ & $7.74(-1)$ & $7.74(-1)$ & $7.74(-1)$ & $7.995(-1)$ \\
\hline NO & $1.05(-4)$ & $1.24(-4)$ & $1.23(-4)$ & $1.003(-11)$ \\
\hline $\mathrm{NO}_{2}$ & $6.77(-5)$ & $4.18(-5)$ & $4.35(-5)$ & $6.027(-12)$ \\
\hline $\mathrm{NO}_{3}$ & $4.52(-8)$ & $2.61(-8)$ & $2.16(-8)$ & $3.598(-15)$ \\
\hline $\mathrm{N}_{2} \mathrm{O}$ & $7.06(-7)$ & $7.60(-7)$ & $7.58(-7)$ & $2.811(-7)$ \\
\hline $\mathrm{N}_{2} \mathrm{O}_{5}$ & 0 & 0 & 0 & $1.65(-13)$ \\
\hline HNO & $6.07(-15)$ & $7.09(-14)$ & $3.95(-13)$ & 0 \\
\hline $\mathrm{HNO}_{2}$ & $1.07(-6)$ & $1.66(-6)$ & $1.57(-6)$ & $3.879(-14)$ \\
\hline $\mathrm{HNO}_{3}$ & $6.26(-10)$ & $3.73(-10)$ & $3.90(-10)$ & $2.271(-10)$ \\
\hline $\mathrm{CH}_{4}$ & $6.56(-23)$ & 0 & $2.42(-20)$ & $1.496(-6)$ \\
\hline $\mathrm{CO}$ & $5.4(-7)$ & $5.45(-7)$ & $5.45(-7)$ & $2.283(-7)$ \\
\hline $\mathrm{CO}_{2}$ & $3.18(-2)$ & $3.15(-2)$ & $3.14(-2)$ & $3.092(-4)$ \\
\hline $\mathrm{CH}_{2} \mathrm{O}$ & $4.99(-13)$ & 0 & 0 & $1.9(-11)$ \\
\hline$\left(\mathrm{CH}_{2} \mathrm{O}\right)$ & $6.08(-5)$ & $6.08(-5)$ & $6.08(-5)$ & $1.9(-11)$ \\
\hline $\mathrm{CH}_{3} \mathrm{O}$ & $1.78(-26)$ & 0 & $4.28(-23)$ & $8.917(-18)$ \\
\hline $\mathrm{CH}_{3} \mathrm{O}_{2}$ & $4.94(-24)$ & 0 & $3.20(-20)$ & $2.71(-12)$ \\
\hline $\mathrm{SO}$ & $6.85(-20)$ & 0 & $1.29(-15)$ & 0 \\
\hline $\mathrm{SO}_{2}$ & $4.76(-9)$ & $5.21(-6)$ & $3.94(-5)$ & $3.793(-9)$ \\
\hline $\mathrm{SO}_{3}$ & $3.78(-10)$ & $4.47(-7)$ & $3.13(-6)$ & 0 \\
\hline HS & $6.6(-28)$ & 0 & $6.16(-24)$ & $1.39(-13)$ \\
\hline $\mathrm{H}_{2} \mathrm{~S}$ & $9.18(-26)$ & 0 & $8.53(-22)$ & $1.26(-9)$ \\
\hline $\mathrm{HSO}_{3}$ & $1.25(-13)$ & $1.51(-10)$ & $8.79(-10)$ & 0 \\
\hline $\mathrm{H}_{2} \mathrm{SO}_{4}$ & $5.54(-11)$ & $6.51(-8)$ & $4.63(-7)$ & $5.06(-13)$ \\
\hline $\mathrm{CS}$ & 0 & 0 & 0 & $1.39(-10)$ \\
\hline $\mathrm{CS}_{2}$ & 0 & 0 & 0 & $9.48(-11)$ \\
\hline COS & 0 & 0 & 0 & $1.644(-9)$ \\
\hline $\mathrm{H}_{3} \mathrm{O}^{+}$ & $8.26(-16)$ & $3.08(-15)$ & $1.52(-14)$ & 0 \\
\hline $\mathrm{H}_{3} \mathrm{O}^{+} \mathrm{H}_{2} \mathrm{O}$ & 0 & 0 & 0 & $6.32(-17)$ \\
\hline $\mathrm{H}_{3} \mathrm{O}^{+}\left(\mathrm{H}_{2} \mathrm{O}\right)_{2}$ & 0 & 0 & 0 & $1.58(-16)$ \\
\hline $\mathrm{H}_{3} \mathrm{O}^{+}\left(\mathrm{H}_{2} \mathrm{O}\right)_{3}$ & 0 & 0 & 0 & $3.16(-17)$ \\
\hline $\mathrm{H}_{3} \mathrm{O}^{+}\left(\mathrm{H}_{2} \mathrm{O}\right)_{4}$ & 0 & 0 & 0 & $6.32(-17)$ \\
\hline $\mathrm{NO}^{+}$ & $2.46(-14)$ & $9.17(-14)$ & $4.54(-13)$ & 0 \\
\hline $\mathrm{NO}_{3}^{-}$ & $6.42(-15)$ & $6.3(-17)$ & $2.1(-18)$ & 0 \\
\hline $\mathrm{NO}_{3}^{-}\left(\mathrm{HNO}_{3}\right)_{2}$ & 0 & 0 & 0 & $6.32(-17)$ \\
\hline $\mathrm{NO}_{3}{ }^{-}\left(\mathrm{HNO}_{3}\right)\left(\mathrm{H}_{2} \mathrm{O}\right)$ & 0 & 0 & 0 & $3.16(-17)$ \\
\hline $\mathrm{HSO}_{4}^{-}$ & $1.31(-14)$ & $9.49(-14)$ & $4.7(-13)$ & 0 \\
\hline $\mathrm{HSO}_{4}^{-}\left(\mathrm{H}_{2} \mathrm{SO}_{4}\right)_{2}$ & 0 & 0 & 0 & $1.58(-16)$ \\
\hline $\mathrm{HSO}_{4}^{-}\left(\mathrm{H}_{2} \mathrm{SO}_{4}\right)_{3}$ & 0 & 0 & 0 & $6.32(-17)$ \\
\hline
\end{tabular}

and $\omega_{\gamma}$ are the rates of variation of the mass of the $\gamma$-th fraction as a result of nucleation, condensation, and coagulation, $\delta_{1 \gamma}$ is the Kroneker symbol. The equations for calculation of $\chi_{0}, \chi_{\gamma}$, and $\omega_{\gamma}$ applied to Euler's method of fractions were described previously. ${ }^{27}$ The kernel of coagulation was calculated in the same manner as in ref. 10. The rate of condensation growth of droplets of the $\gamma$-th fraction was calculated in accordance with the Hertz-Knudsen kinetic model for the free molecular mode taking the Kelvin correction into account. In our consideration, as in ref. 10, we have assumed an accommodation (sticking) coefficient for $\mathrm{H}_{2} \mathrm{SO}_{4}$ molecules of unity.
The range $\left[0, r_{\Gamma}\right]$ (with $r_{\Gamma}=224 \mathrm{~nm}$ ) was subdivided into a number $\Gamma=140$ of fractions. This number was found sufficient for convergence of the particle size distribution function for increasing subdivision. The principal differences between the Q1D model and box models as applied by $\mathrm{Yu}$ and Turco ${ }^{16}$ and by Kärcher, ${ }^{41}$ is that the Q1D model makes it possible to calculate directly the plume cross section area, temperature, and species concentration evolution along the plume for bypass jet engines including mixing of the core and the bypass jets with ambient air. Another benefit of our approach is that this model simulates the kinetics of various ion cluster formation in detail. 

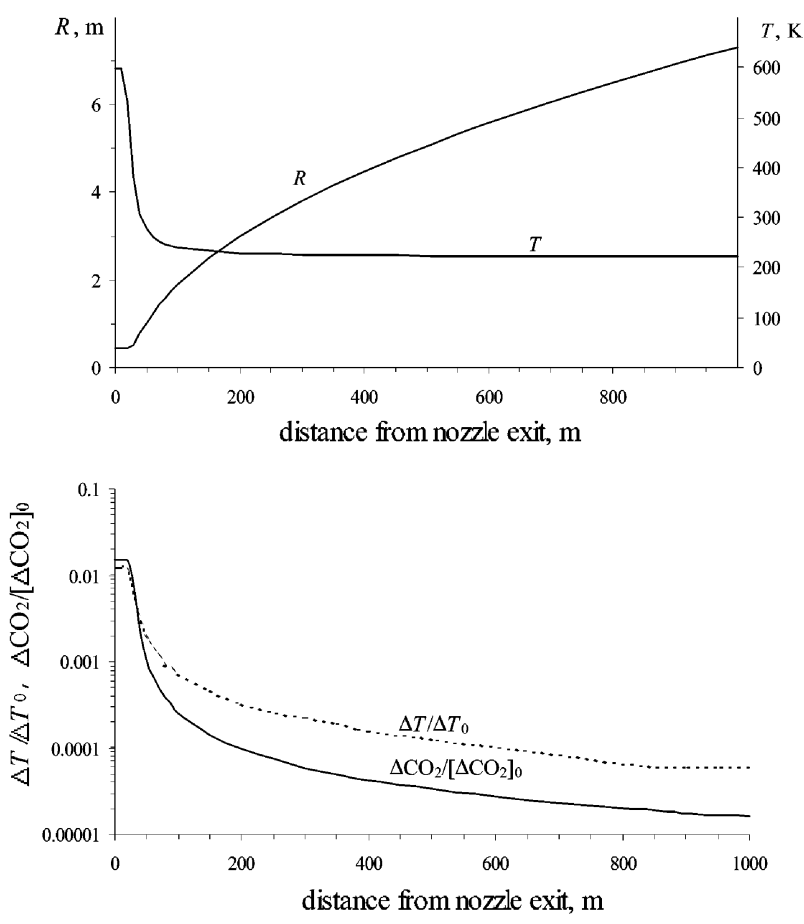

Fig. 1 Evolution of plume radius, $R$, temperature, $T$, normalized temperature difference, $\Delta T$, and normalized excess carbon dioxide mole fraction, $\Delta \mathrm{CO}_{2}$, versus distance from the nozzle exit along the plume axis of a B-747 aircraft at $10.7 \mathrm{~km}$.

Analysis of the results has shown that the chemical processes of ion cluster production as well as the evolution of the gaseous species $\mathrm{NO}_{x}, \mathrm{HNO}_{y}, \mathrm{~N}_{2} \mathrm{O}_{5}, \mathrm{HO}_{z}, \mathrm{SO}_{x}, \mathrm{HSO}_{3}, \mathrm{H}_{2} \mathrm{SO}_{4}$ are controlled in the plume by kinetics and exhibit a nonequilibrium behavior. Moreover, the computations show that both model cases (1) and (2) of approximation of GSA formation result in approximately the same GSA concentrations in the plume.

\section{Effect of S-containing species on the formation of volatile aerosols in the young plume}

As shown previously ${ }^{21,42}$ an increase of $\mathrm{SO}_{3}$ concentration at the nozzle exit results in a growth of the size and number density of volatile aerosol particles. Previous analysis prescribed the $\mathrm{SO}_{3}$ concentration as a free model parameter and did not take into account the presence of $\mathrm{HSO}_{3}$ and $\mathrm{H}_{2} \mathrm{SO}_{4}$ species at the nozzle exit besides $\mathrm{SO}_{3}$. However these species may be abundant in the nozzle exhaust as a result of strong oxidation of $\mathrm{SO}_{2}$ and $\mathrm{SO}_{3}$ inside the turbine and in the nozzle flow. ${ }^{39,43}$ To estimate the effect of $\mathrm{SO}_{3}, \mathrm{HSO}_{3}$, and $\mathrm{H}_{2} \mathrm{SO}_{4}$ production in the combustor and in the turbine and nozzle flow on the formation of sulfate aerosols, we have compared the results of the full model (the standard case) with results obtained if all S-containing molecules leave the nozzle exit as $\mathrm{SO}_{2}$. In the latter case the concentration of $\mathrm{SO}_{2}$ is prescribed at the nozzle exit such that the same sum of $\mathrm{S}$-containing species is emitted in both cases, i.e. $\mathrm{EI}\left(\mathrm{SO}_{2}+\mathrm{SO}_{3}+\mathrm{HSO}_{3}+\mathrm{H}_{2} \mathrm{SO}_{4}\right)=\mathrm{EI}\left(\mathrm{SO}_{2}\right)$.

Because of burning S-containing air (see Table 2), $\mathrm{SO}_{3}$ and $\mathrm{H}_{2} \mathrm{SO}_{4}$ molecules are abundant in the nozzle exhaust even for $\mathrm{FSC}=0 \%$. The abundance of $\mathrm{SO}_{3}$ and $\mathrm{H}_{2} \mathrm{SO}_{4}$ in the emitted gases results in formation of sulfate aerosols in the near field plume (at $\sim 100 \mathrm{~m}$ distance from the nozzle exit). But the diameter of these volatile particles remains small (less than $1.2 \mathrm{~nm}$ ) and the concentration of the particles with $d>1 \mathrm{~nm}$ is around $5 \times 10^{4} \mathrm{~cm}^{-3}$, i.e., a factor of $10^{4}$ smaller than for FSC $=0.3 \%$ (see Table 2). The small size of sulfate aerosol particles and relatively low particle concentration at
FSC $=0 \%$ is caused by the low nucleation rate due to small $\mathrm{H}_{2} \mathrm{SO}_{4}$ partial pressure in the engine exhaust. It should be noted that the abundance of a significant amount of gaseous $\mathrm{H}_{2} \mathrm{SO}_{4}$ and small sulfate volatile particles $(d \approx 0.8-1 \mathrm{~nm})$ in the aircraft plume even for sulfur free fuel can lead to heterogeneous condensation of $\mathrm{H}_{2} \mathrm{O} / \mathrm{H}_{2} \mathrm{SO}_{4}$ on the surface of soot and to coagulation between sulfate aerosols and soot particles, and this may cause contrail formation at corresponding conditions.

In comparison with the case when only $\mathrm{SO}_{2}$ is present at the nozzle exit, our analysis of the standard case shows that the abundance of $\mathrm{SO}_{3}, \mathrm{HSO}_{3}$, and $\mathrm{H}_{2} \mathrm{SO}_{4}$ species in the nozzle exhaust leads to an increase of $\mathrm{H}_{2} \mathrm{SO}_{4}$ partial pressure, nucleation rate, sulfur conversion efficiency, intensification of coagulation processes, change in the particle size distribution, and increase of a number of larger size volatile aerosols in the near field plume. Fig. 2 depicts the evolution of the $\mathrm{H}_{2} \mathrm{O} / \mathrm{H}_{2} \mathrm{SO}_{4}$ volatile aerosol number density, $N_{\mathrm{a}}$, with different diameters $d$ along the aircraft plume axis for FSC $=0 \%$ (a), $0.04 \%$ (b), and $0.3 \%$ (c) for both the standard case and the case when only $\mathrm{SO}_{2}$ is abundant at the nozzle exit. For sulfur free fuel and only $\mathrm{SO}_{2}$ present in the emitted gases, no sulfate aerosols form in the plume. At low fuel sulfur content $(\mathrm{FSC}=0.04 \%)$ the concentration of sulfate aerosol particles with $d>5 \mathrm{~nm}$ stays below $10^{4} \mathrm{~cm}^{-3}$ even at a distance of $1000 \mathrm{~m}$ from the nozzle exit, even when $\mathrm{SO}_{3}, \mathrm{HSO}_{3}$, and $\mathrm{H}_{2} \mathrm{SO}_{4}$ are produced in the
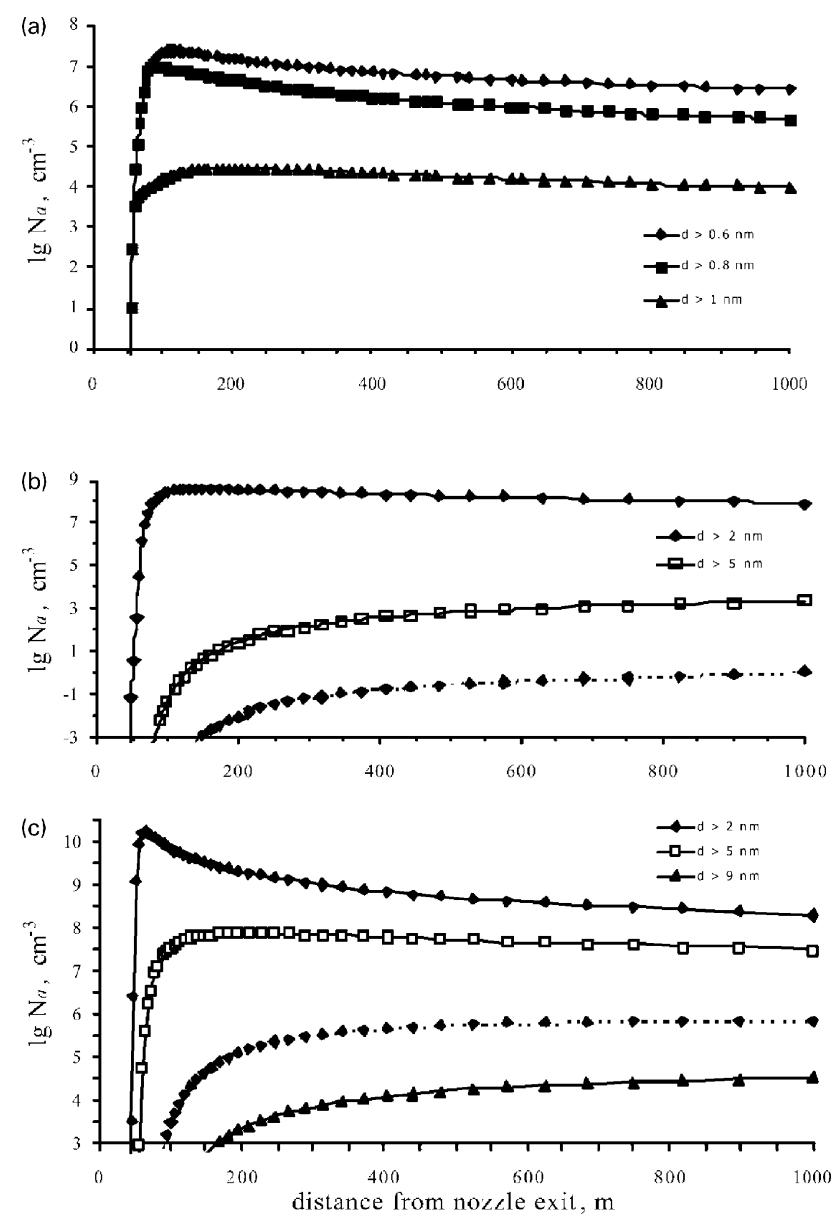

Fig. 2 Evolution of the number density of volatile $\mathrm{H}_{2} \mathrm{O} / \mathrm{H}_{2} \mathrm{SO}_{4}$ aerosol particles with particle diameters larger than a given size $d$ along the plume axis of a B-747 aircraft at $10.7 \mathrm{~km}$ for $\mathrm{FSC}=0 \%$ (a); $0.04 \%$ (b) and $0.3 \%$ (c) for two cases of initial S-containing species abundance at the engine exit: all S-containing species are abundant (solid curves) and only $\mathrm{SO}_{2}$ is abundant (dotted curves). The computed concentration for the case when only $\mathrm{SO}_{2}$ is abundant at the engine exit stays below the scale plotted for particles with $d>0.8 \mathrm{~nm}$ and $1 \mathrm{~nm}$ in (a); with $d>5 \mathrm{~nm}$ in (b) and $d>5$ and $9 \mathrm{~nm}$ in (c). 
engine. If only $\mathrm{SO}_{2}$ is abundant at the nozzle exit, the concentration of such aerosols is negligible. Schröder et al. ${ }^{8}$ measured large concentrations, of about $10^{6} \mathrm{~cm}^{-3}$, of relatively large volatile particles with $d>5 \mathrm{~nm}$ in the near field plume of the ATTAS aircraft for lower FSC $=0.026 \%$. These results cannot be explained by the formation of sulfate aerosol precursors $\left(\mathrm{SO}_{3}, \mathrm{HSO}_{3}, \mathrm{H}_{2} \mathrm{SO}_{4}\right)$ in the combustor. Instead, emitted condensable hydrocarbons and chemi-ions were considered to be responsible for the generation of the observed large volatile aerosols in the aircraft plume. ${ }^{37,44}$

For $\mathrm{FSC}=0.3 \%$, the aerosol precursors $\left(\mathrm{SO}_{3}, \mathrm{HSO}_{3}\right.$, $\mathrm{H}_{2} \mathrm{SO}_{4}$ ) produced in the internal flow of the engine cause a significant (by a factor of 100 compared to the case with pure $\mathrm{SO}_{2}$ emissions) increase of the number density of sulfate aerosols with $d>5 \mathrm{~nm}$. In this case the concentration of sulfate aerosol particles with $d>5 \mathrm{~nm}$ reaches $10^{8} \mathrm{~cm}^{-3}$. This value of sulfate volatile particle concentration is in agreement with measurements by Petzold et al. ${ }^{45}$ for a B-737 aircraft. An increase of FSC from $0.04 \%$ to $0.3 \%$ leads to the formation of a considerable amount $\left(N_{\mathrm{a}} \sim 5 \times 10^{4} \mathrm{~cm}^{-3}\right)$ of even larger size volatile aerosols $(d>9 \mathrm{~nm})$. But the concentration of these particles is smaller than the value of $N_{\mathrm{a}}(d>9 \mathrm{~nm})$ observed in a B-737 plume by Petzold et al. ${ }^{45}$ and in an ATTAS plume by Schröder et $a l^{8}{ }^{8}$ Aerosol concentrations of the magnitude computed have been observed during in-flight measurements by Fahey et al., ${ }^{4}$ but in far older plumes ( $>15 \mathrm{~min}$ ).

The computed efficiency of conversion (mole fraction) of $\mathrm{SO}_{2} \rightarrow \mathrm{SO}_{3}+\mathrm{H}_{2} \mathrm{SO}_{4} \quad(\varepsilon)$ is $12.7 \%$ for $\mathrm{FSC}=0.04 \%$ and $11.8 \%$ for $\mathrm{FSC}=0.3 \%$. The value of $\varepsilon$ in the plume depends strongly on the $\mathrm{SO}_{2}$ conversion efficiency and on the calculation model used for turbine and nozzle flow. This fact is illustrated by Fig. 3, which depicts the evolution of the conversion efficiency, $\varepsilon$, along the plume axis of the aircraft at $\mathrm{FSC}=0.3 \%$ for two values of $\varepsilon$ at the nozzle exit: $\varepsilon=9.8 \%$ was calculated using the Q1D $\operatorname{model}^{39}$ and $\varepsilon=2.9 \%$ was calculated using the box model with a linear temperature decrease from combustor to nozzle exits ${ }^{46}$ (curves 1 and 2, respectively). Hence, details of thermodynamics in the engine are important for the conversion efficiency $\varepsilon$. The change in $\varepsilon$ has a strong impact on the aerosol formation, as is to be expected. This can be seen from Fig. 4, which shows the evolution of the number density of volatile sulfate particles with different diameters in the aircraft plume for both cases. For the smaller $\varepsilon$ computed by the box model, the aerosol number density with $d>5 \mathrm{~nm}$ in the plume is significantly smaller, far less than measured, ${ }^{8,45}$ and particles larger than $9 \mathrm{~nm}$ are rare in this case. The concentration of small sulfate aerosols with $d>2 \mathrm{~nm}$ is affected by the value of $\varepsilon$ only weakly. The larger concentration of sulfate aerosol particles with $d>5 \mathrm{~nm}$ and formation of particles larger than $9 \mathrm{~nm}$ at high $\varepsilon(\varepsilon=9.8 \%)$ as compared to smaller $\varepsilon$ are caused by the larger concentration of GSA in the young plume for

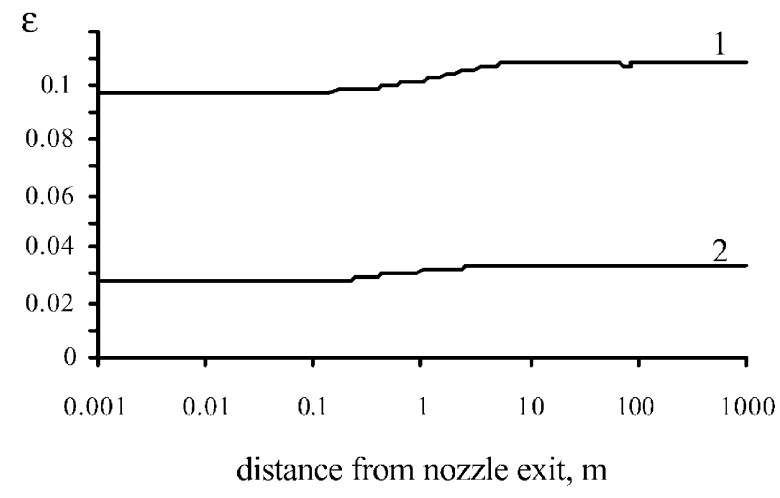

Fig. 3 Evolution of sulfur conversion efficiency along the plume axis for two models for calculation of parameters in postcombustor flow.

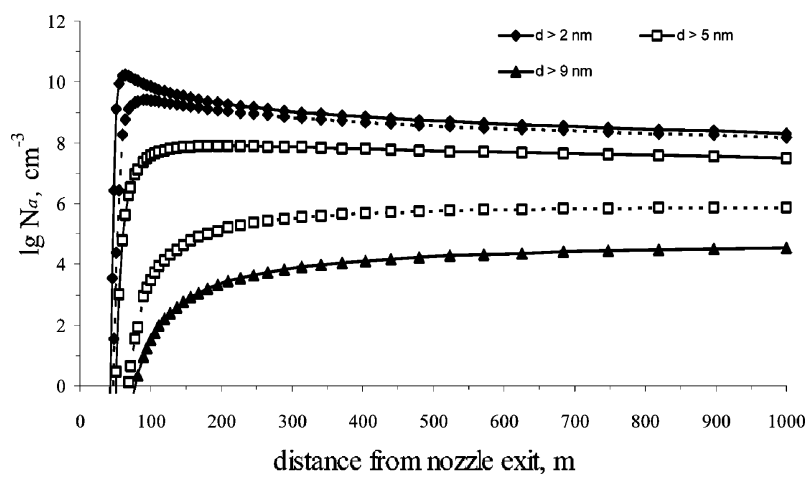

Fig. 4 Evolution of the number density of volatile $\mathrm{H}_{2} \mathrm{O} / \mathrm{H}_{2} \mathrm{SO}_{4}$ aerosol particles exceeding the given particle sizes $d$ along the plume axis for two different models for calculation of parameters in turbine and nozzle flow. The solid lines represent the results of the Q1D-model and the dotted lines those of the box model with prescribed temperature and pressure histories.

$\varepsilon=9.8 \%$. This results in larger nucleation and condensation rates. As a consequence the small particles $(d \approx 1-2 \mathrm{~nm})$ form at a short distance from the nozzle exit $(\sim 40 \mathrm{~m})$. Coagulation of these particles produces the larger aerosols with $d>5 \mathrm{~nm}$ and even particles with $d>9 \mathrm{~nm}$.

Fig. 5 depicts the GSA mole fraction and $\xi$, the ratio of GSA concentration relative to the total sulfuric acid concentration (including any fraction contained in liquid aerosols), as a function of plume age for the case when all S-containing species are abundant at the engine exit and for $\mathrm{FSC}=0 \%$ and $0.3 \%$. One can see that the concentration of gaseous $\mathrm{H}_{2} \mathrm{SO}_{4}$ rapidly decreases due to the gas-to-particle conversion up to the plume age around $1 \mathrm{~s}$. The slight growth of GSA mole fraction after $t=1 \mathrm{~s}$ may be explained by continued oxidation of $\mathrm{SO}_{2}$, which concentration for $\mathrm{FSC}=0.3 \%$ at the distance $\sim 240 \mathrm{~m}$ is as large as $1.5 \times 10^{12} \mathrm{~cm}^{-3}$. The value of $\xi$ rapidly drops with increasing distance from the engine exit. For FSC $=0.3 \%$ $\%$ the value of $\xi$ at a plume age around $1 \mathrm{~s}$ is $10^{5}$ times smaller than at the nozzle exit. At FSC $=0 \%$ the value of $\xi$ is much larger and remains larger than $10^{-1}$. Hence, the gas-to-particle conversion at $\mathrm{FSC}=0 \%$ is smaller by a factor of $10^{4}$ than at FSC $=0.3 \%$. This is caused by the smaller partial GSA pressure and supersaturation value at $\mathrm{FSC}=0 \%$. As a consequence, the nucleation and condensation rates are much

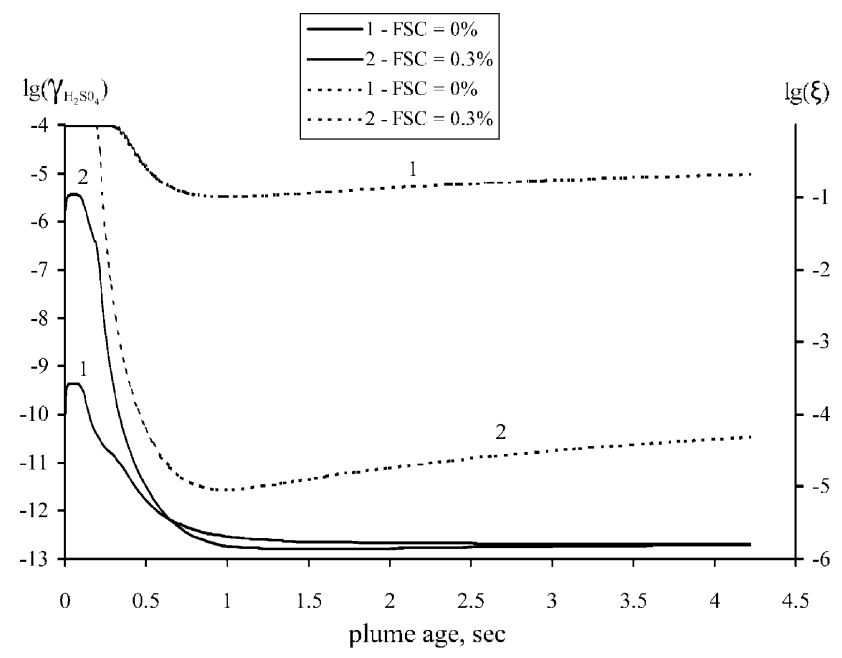

Fig. 5 Evolution of the mole fraction of gaseous sulfuric acid, $\gamma_{\mathrm{H}_{2} \mathrm{SO} 4}$, (solid line) and of the ratio of gaseous sulfuric acid concentration relative to the total sulfuric acid concentration including gaseous and liquid phase, $\xi$, (dotted line) versus plume age for $\mathrm{FSC}=0 \%$ and $0.3 \%$ (curves 1,2 ). 
smaller than for $\mathrm{FSC}=0.3 \%$. The increase of $\xi$ values in the plume at plume ages larger than $1 \mathrm{~s}$ for both $\mathrm{FSC}=0 \%$ and $0.3 \%$ is caused by the slight growth of GSA concentration due to oxidation of $\mathrm{SO}_{2}$ to $\mathrm{H}_{2} \mathrm{SO}_{4}$ and possibly by the decrease of the total sulfate aerosol number density after $t=1 \mathrm{~s}$ (see Fig. 2) due to dilution of the plume. The computed gaseous $\mathrm{H}_{2} \mathrm{SO}_{4}$ concentration at a distance of about $240 \mathrm{~m}$ from the nozzle exit does not exceed $1.63 \times 10^{7} \mathrm{~cm}^{-3}$ at $\mathrm{FSC}=0.3 \%$. This finding is in a good agreement with the estimated value of GSA concentration $\leq 1.7 \times 10^{8} \mathrm{~cm}^{-3}$ obtained from measurements by Arnold et al. ${ }^{13}$

\section{Gas-phase mechanisms of ion cluster formation in young plume}

Recent studies ${ }^{24}$ have shown that a number of different ions are abundant in the nozzle exhausts of jet engines, mainly $\mathrm{HSO}_{4}{ }^{-}, \mathrm{NO}_{3}{ }^{-}, \mathrm{NO}^{+}$, and $\mathrm{H}_{3} \mathrm{O}^{+}$. The ion composition at the nozzle exit strongly depends on the value of FSC. This is seen from the results of our modeling listed in Table 2. For $\mathrm{FSC}=0 \%$ the concentration of $\mathrm{NO}_{3}{ }^{-}$ions is a factor of $10^{4}$ larger than for $\mathrm{FSC}=0.3 \%$ and, conversely, the concentration of $\mathrm{H}_{3} \mathrm{O}^{+}$ions is a factor of 20 smaller. It is also known that ambient air may contain charged clusters. ${ }^{15,28}$ The total concentration of such clusters does not exceed $5000 \mathrm{~cm}^{-3}$. The concentration of ions at the engine exit is far higher than in ambient air and further clustering of ions occurs when the exhaust products cool during expansion in the aircraft plume.
Therefore, ions that nucleate from galactic cosmic rays are of small importance for ion formation in the young exhaust plume.

Our model calculations have shown that the abundance of $\mathrm{NO}_{3}{ }^{-}, \mathrm{HSO}_{4}^{-}, \mathrm{NO}^{+}$, and $\mathrm{H}_{3} \mathrm{O}^{+}$at the nozzle exhaust leads to the generation of negative $\mathrm{HSO}_{4}{ }^{-}\left(\mathrm{H}_{2} \mathrm{SO}_{4}\right)_{m}$, $\mathrm{HSO}_{4}{ }^{-}\left(\mathrm{HNO}_{3}\right)_{m-1}(m=1 \ldots 3), \mathrm{NO}_{3}{ }^{-}\left(\mathrm{HNO}_{3}\right)_{q}(q=1 \ldots 5)$, $\mathrm{NO}_{3}{ }^{-}\left(\mathrm{HNO}_{3}\right)\left(\mathrm{H}_{2} \mathrm{O}\right)$ and positive $\mathrm{H}_{3} \mathrm{O}^{+}\left(\mathrm{CH}_{2} \mathrm{O}\right)\left(\mathrm{H}_{2} \mathrm{O}\right)_{m}$, $\mathrm{H}_{3} \mathrm{O}^{+}\left(\mathrm{H}_{2} \mathrm{O}\right)_{n}(n=1-6)$ ion clusters in the plume. The scheme of negative and positive ion cluster formation in the near field plume is presented in Fig. 6. It should be noted that at very short distances from the nozzle exit $\mathrm{NO}^{+}$ions react with $\mathrm{H}_{2} \mathrm{O}$ and form charged clusters $\mathrm{NO}^{+}\left(\mathrm{H}_{2} \mathrm{O}\right)_{m}$. But very rapidly these clusters transform to the $\mathrm{H}_{3} \mathrm{O}^{+}\left(\mathrm{H}_{2} \mathrm{O}\right)_{m}$ clusters due to the reaction $\mathrm{NO}^{+}\left(\mathrm{H}_{2} \mathrm{O}\right)_{3}+\mathrm{H}_{2} \mathrm{O}=\mathrm{H}_{3} \mathrm{O}^{+}\left(\mathrm{H}_{2} \mathrm{O}\right)_{2}+\mathrm{HNO}_{2}$. This is clearly seen from Fig. 7, which depicts the evolution of different ion cluster mole fractions along the plume axis of the aircraft at cruise for $\mathrm{FSC}=0.3 \%$ and for small $\mathrm{CH}_{2} \mathrm{O}$ concentrations $\left(\gamma_{\mathrm{CH}_{2} \mathrm{O}}=4.99 \times 10^{-13}\right)$. Among the negative and the positive ion clusters, $\mathrm{HSO}_{4}{ }^{-}\left(\mathrm{H}_{2} \mathrm{SO}_{4}\right)_{3}$ and $\mathrm{H}_{3} \mathrm{O}^{+}\left(\mathrm{H}_{2} \mathrm{O}\right)_{2}$ are the most abundant ones, respectively. Fig. 8 depicts the evolution of different positively charged cluster mole fractions along the plume axis in the case of high formaldehyde concentrations $\left(\gamma_{\mathrm{CH}_{2} \mathrm{O}}=6.08 \times 10^{-5}\right)$. In this case, $\mathrm{H}_{3} \mathrm{O}^{+}\left(\mathrm{CH}_{2} \mathrm{O}\right)$ and $\mathrm{H}_{3} \mathrm{O}^{+}\left(\mathrm{CH}_{2} \mathrm{O}\right)\left(\mathrm{H}_{2} \mathrm{O}\right)_{2}$ are the most abundant among all the positive ion clusters. Our model computes a total concentration of positive ions of about $1.5 \times 10^{6} \mathrm{~cm}^{-3}$ in the plume $1 \mathrm{~m}$ behind the engine exit at $\mathrm{FSC}=0.3 \%$. Arnold et $a l^{15}$ measured a total concentration of positive ions of
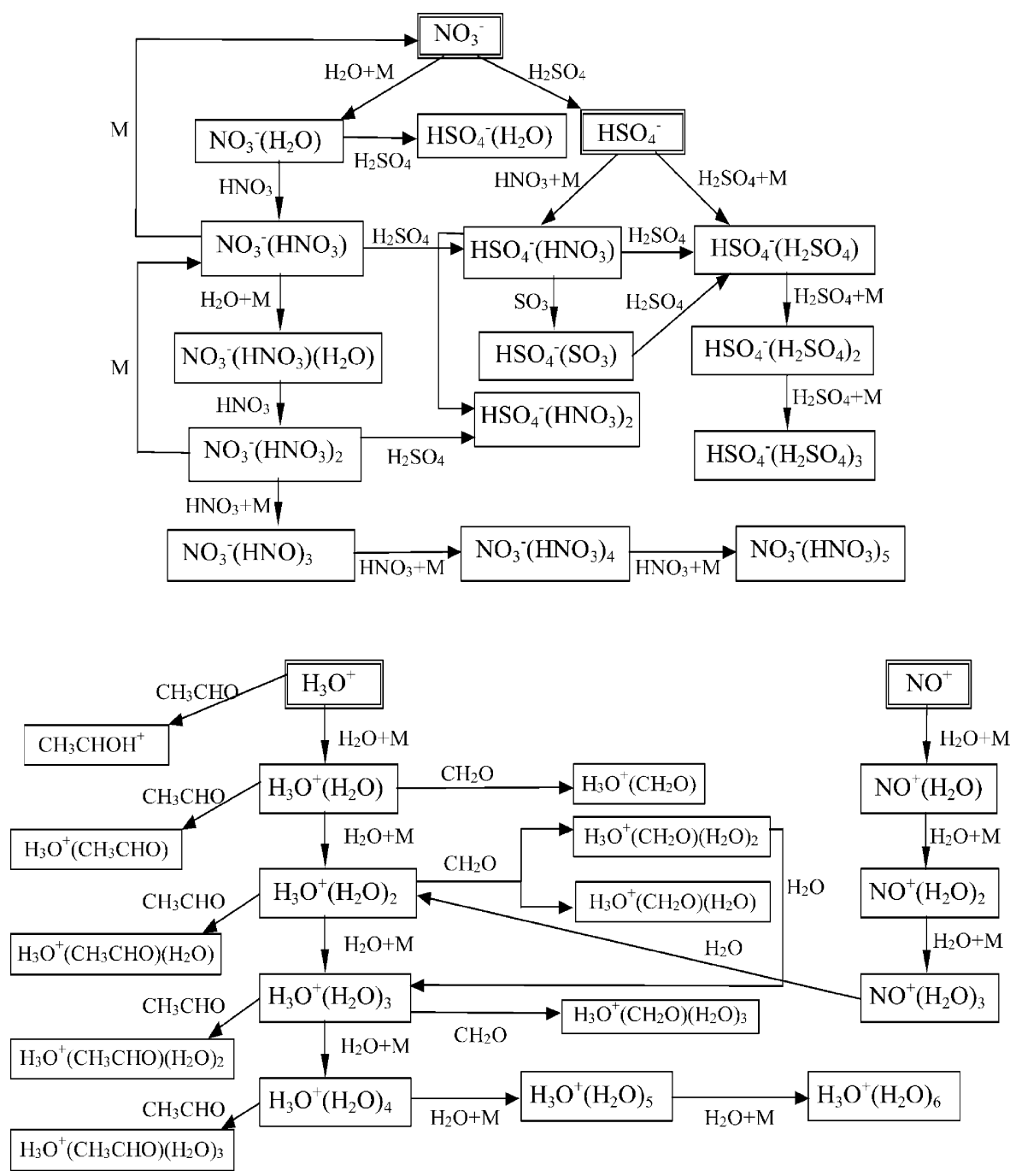

Fig. 6 The scheme of negative and positive ion cluster formation in young plume represented in the model. 

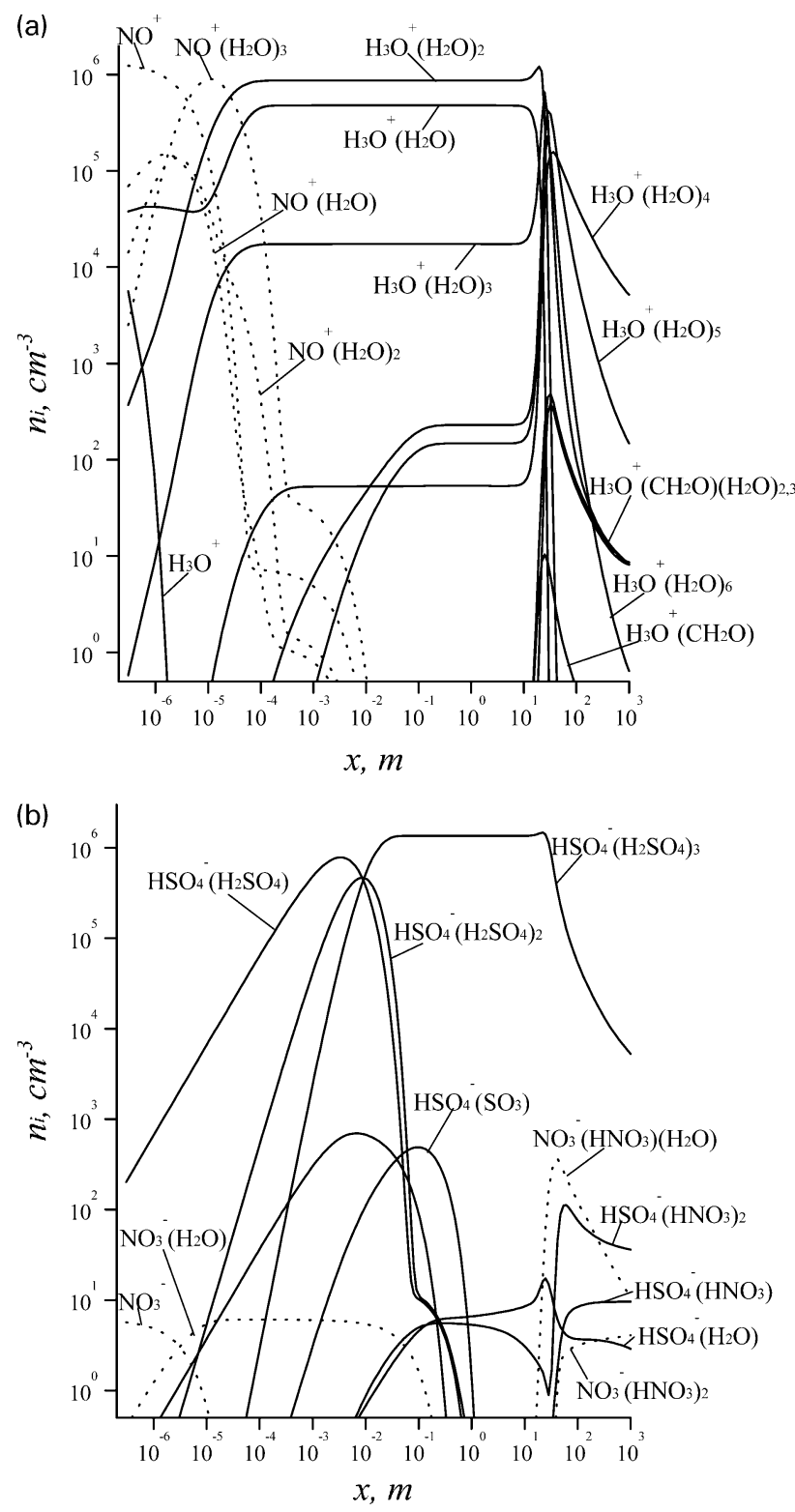

Fig. 7 Evolution of positive (a) and negative (b) ion cluster mole fractions along the plume axis for $\mathrm{FSC}=0.3 \%$ when $\mathrm{CH}_{2} \mathrm{O}$ is absent in the nozzle exhaust.

$1.2 \times 10^{8} \mathrm{~cm}^{-3}$ at about the same distance from the engine exit at ground. Differences between ion concentrations observed at ground and computed at cruise are to be expected because of several reasons. One of them is the difference in pressure and temperature values in the engine combustor for cruise and ground conditions. ${ }^{24}$ Another may be connected with inaccuracy of the modeling of the combustion processes in the aero-engine combustor. To compute the concentration of different ions at the combustor exit we have assumed premixed homogeneous burning in the model. Real aero-engine combustion chambers operate in a diffusion mode, with inhomogeneous distributions of fuel/air equivalence ratio and temperature in the combustor. In the homogeneous case of the model, the temperature remains around $1600 \mathrm{~K}$. In the inhomogeneous case in reality, a narrow region with relatively high temperature ( $T \sim 2000-2200 \mathrm{~K}$ ) forms near the axis of the combustor. This may lead to the formation of ions at higher concentrations at the combustor exit than computed. The third reason is that heavy hydrocarbon ions such as $\mathrm{C}_{19} \mathrm{H}_{11}{ }^{+}$, $\mathrm{C}_{22} \mathrm{H}_{12}{ }^{+}, \mathrm{C}_{59} \mathrm{H}_{19}{ }^{+}$, and others, may form in the enriched fuel zone of the combustor. Such heavy hydrocarbon ions are not included in the model but may add considerably to the total

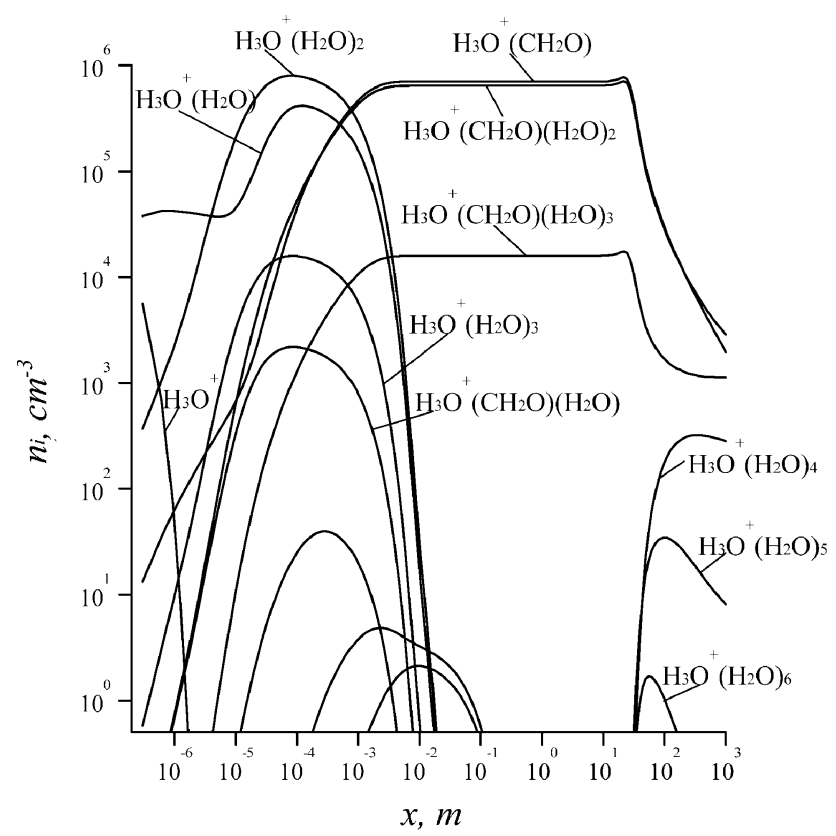

Fig. 8 Evolution of mole fractions of positive ion clusters along the plume axis for $\mathrm{FSC}=0.3 \%$ when $\mathrm{CH}_{2} \mathrm{O}$ is abundant at the nozzle exit $\left(\mathrm{EI}\left(\mathrm{CH}_{2} \mathrm{O}\right)=23 \mathrm{mg} \mathrm{kg}^{-1}\right)$.

ion concentration. A larger abundance of ions at the engine exit would also cause larger ion concentrations in the exhaust plume.

Arnold et al. ${ }^{12}$ measured a total negative ion concentration of larger than $1.6 \times 10^{7} \mathrm{~cm}^{-3}$ at plume ages of around $10 \mathrm{~ms}$ in the exhaust of the jet engine of the ATTAS aircraft on the ground. Negative ions observed inside the plume of an Airbus A310 in flight at altitudes around $10.4 \mathrm{~km}$ were found to be mostly $\mathrm{HSO}_{4}^{-}\left(\mathrm{H}_{2} \mathrm{SO}_{4}\right)_{m}, \mathrm{HSO}_{4}^{-}\left(\mathrm{HNO}_{3}\right)_{n}$ and $\mathrm{NO}_{3}{ }^{-}\left(\mathrm{HNO}_{3}\right)_{m}$ with $m$ and $n \leq 2 .{ }^{13}$ An upper limit for negative and positive ion concentration was estimated as $2.8 \times 10^{5}-2.8 \times 10^{6} \mathrm{~cm}^{-3}$ on the basis of measurements. Our model computes a similar ion composition. At a distance around $10 \mathrm{~m}$ from the engine exit, the concentration of $\mathrm{HSO}_{4}^{-}\left(\mathrm{H}_{2} \mathrm{SO}_{4}\right)_{3}$ clusters reaches $\sim 1.4 \times 10^{6} \mathrm{~cm}^{-3}$, and at a distance of $50 \mathrm{~m}$ its concentration decreases to $1.5 \times 10^{5} \mathrm{~cm}^{-3}$. The concentration of positive ion clusters $\mathrm{H}_{3} \mathrm{O}^{+}\left(\mathrm{H}_{2} \mathrm{O}\right)_{2}$ and $\mathrm{H}_{3} \mathrm{O}^{+} \mathrm{H}_{2} \mathrm{O}$ drops from $1.4 \times 10^{6} \mathrm{~cm}^{-3}$ at $x=10 \mathrm{~m}$ up to $2.5 \mathrm{~cm}^{-3}$ at $x=50 \mathrm{~m}$. But in this interval the concentration of larger ion clusters with the $\mathrm{H}_{3} \mathrm{O}^{+}$core such as $\mathrm{H}_{3} \mathrm{O}^{+}\left(\mathrm{H}_{2} \mathrm{O}\right)_{4}$ and $\mathrm{H}_{3} \mathrm{O}^{+}\left(\mathrm{H}_{2} \mathrm{O}\right)_{5}$ grows up to $1.5 \times 10^{5} \mathrm{~cm}^{-3}$. These values of ion cluster concentration are in good agreement with the reported upper limit for ion concentration obtained from in-flight measurements by Arnold et al. ${ }^{13}$ Some differences between the model and the experimental results were to be expected because of the differences in the engines and atmospheric conditions.

The decrease of FSC leads to a strong increase of $\mathrm{NO}_{3}{ }^{-}\left(\mathrm{HNO}_{3}\right)\left(\mathrm{H}_{2} \mathrm{O}\right)$ and $\mathrm{HSO}_{4}{ }^{-}\left(\mathrm{HNO}_{3}\right)_{2}$ concentrations and a decrease of the concentration of $\mathrm{HSO}_{4}{ }^{-}$-core ion clusters. It should be noted that even at $\mathrm{FSC}=0 \%$ the clusters $\mathrm{HSO}_{4}{ }^{-}\left(\mathrm{H}_{2} \mathrm{SO}_{4}\right)_{2}$ and $\mathrm{HSO}_{4}{ }^{-}\left(\mathrm{H}_{2} \mathrm{SO}_{4}\right)_{3}$ may form in the plume. Certainly, the concentration of positive and negative ion clusters in this case is lower than at larger FSC values. The number density of most of the considered ion clusters continues to decrease with distance from the nozzle exit. At a distance of $\sim 240 \mathrm{~m}$, the concentration of $\mathrm{HSO}_{4}{ }^{-}\left(\mathrm{H}_{2} \mathrm{SO}_{4}\right)_{3}$ ion clusters decreases to $2 \times 10^{4} \mathrm{~cm}^{-3}$ for $\mathrm{FSC}=0.3 \%$. The concentration of $\mathrm{HSO}_{4}^{-}\left(\mathrm{HNO}_{3}\right)_{2}$ ion clusters becomes lower than the concentration of negative ions in the background atmosphere. The changes of temperature, neutral species and ion cluster concentrations in the near field plume at various distances $(x)$ from the nozzle exit and different FSC values for low 
concentrations of $\mathrm{CH}_{2} \mathrm{O}$ at the nozzle exit are illustrated by the data listed in Table 3.

The computations have shown that the concentration of ion clusters may be about $10^{5} \mathrm{~cm}^{-3}$ at $\sim 50 \mathrm{~m}$ distance from the nozzle exit for a low value of FSC. The number density of the aerosol particles larger than $5 \mathrm{~nm}$ measured in the engine plume in flight by Schröder et al. ${ }^{8}$ was about $10^{6} \mathrm{~cm}^{-3}$ at low FSC. The computed concentration of particles with $d>5 \mathrm{~nm}$ for low FSC $(0.04 \%)$ at the same distance from the nozzle exit does not exceed $10^{4} \mathrm{~cm}^{-3}$. Therefore the larger observed concentration of volatile aerosol particles with $d>5 \mathrm{~nm}$ at low FSC values is expected to be due to the engine emission of the other condensable gases (organic species) and possible promotion of the aerosol growth via the ion clusters-assisted coagulation of small (with $d \sim 2 \mathrm{~nm}$ ) particles. Besides $\mathrm{HSO}_{4}^{-}\left(\mathrm{H}_{2} \mathrm{SO}_{4}\right)_{m}, \mathrm{HSO}_{4}^{-}\left(\mathrm{HNO}_{3}\right)_{m}, \mathrm{H}_{3} \mathrm{O}^{+}\left(\mathrm{H}_{2} \mathrm{O}\right)_{m}$ or $\mathrm{H}_{3} \mathrm{O}^{+}\left(\mathrm{CH}_{2} \mathrm{O}\right)\left(\mathrm{H}_{2} \mathrm{O}\right)_{m}$ charged clusters, other ions, mostly heavy hydrocarbon ions formed in the fuel-rich region of the aero-engine combustor, and organic ion clusters such as $\mathrm{H}^{+} \mathrm{X}\left(\mathrm{H}_{2} \mathrm{O}\right)_{n}, \mathrm{X}=\mathrm{CH}_{2} \mathrm{O}, \mathrm{CH}_{3} \mathrm{OH}, \mathrm{C}_{2} \mathrm{H}_{4}, \mathrm{C}_{2} \mathrm{H}_{6}$ may be abundant in the near field plume but are not included in the model. The presence of significant amounts of ion clusters

Table 3 Temperature and species number density $\left(\mathrm{cm}^{-3}\right)$ at different sections of the aircraft plume for FSC $=0 \%, 0.04 \%$ and $0.3 \%$ without $\mathrm{CH}_{2} \mathrm{O}^{a}$

\begin{tabular}{|c|c|c|c|c|c|c|c|c|c|}
\hline \multirow{4}{*}{$\begin{array}{l}x / \mathrm{m} \\
T / \mathrm{K}\end{array}$} & \multicolumn{3}{|l|}{1} & \multicolumn{3}{|l|}{40} & \multicolumn{3}{|l|}{240} \\
\hline & \multicolumn{3}{|l|}{ FSC } & \multicolumn{3}{|l|}{ FSC } & \multicolumn{3}{|l|}{ FSC } \\
\hline & $0 \%$ & $0.04 \%$ & $0.3 \%$ & $0 \%$ & $0.04 \%$ & $0.3 \%$ & $0 \%$ & $0.04 \%$ & $0.3 \%$ \\
\hline & 598 & & & 304 & & & 227 & & \\
\hline $\mathrm{H}_{2} \mathrm{O}$ & $1.16(+17)$ & $1.15(+17)$ & $1.15(+17)$ & $3.6(+16)$ & $3.66(+16)$ & $3.0(+16)$ & $1.93(+15)$ & $1.92(+15)$ & $1.94(+15)$ \\
\hline $\mathrm{O}_{2}$ & $4.47(+17)$ & $4.47(+17)$ & $4.47(+17)$ & $1.08(+18)$ & $1.08(+18)$ & $1.13(+18)$ & $1.53(+18)$ & $1.53(+18)$ & $1.53(+18)$ \\
\hline $\mathrm{H}_{2}$ & $8.9(+10)$ & $6.18(+10)$ & $6.19(+10)$ & $4.47(+12)$ & $4.42(+12)$ & $4.77(+12)$ & $7.13(+12)$ & $7.12(+12)$ & $7.12(+12)$ \\
\hline $\mathrm{OH}$ & $1.62(+12)$ & $1.82(+12)$ & $1.13(+12)$ & $3.62(+6)$ & $4.09(+6)$ & $4.01(+6)$ & $6.88(+5)$ & $7.02(+5)$ & $7.09(+5)$ \\
\hline $\mathrm{O}_{3}$ & $6.67(+10)$ & $1.73(+11)$ & $3.43(+11)$ & $3.04(+11)$ & $2.95(+11)$ & $3.25(+11)$ & $5.41(+11)$ & $5.39(+11)$ & $5.39(+11)$ \\
\hline $\mathrm{HO}_{2}$ & $6.2(+8)$ & $5.67(+9)$ & $2.89(+10)$ & $1.03(+6)$ & $1.04(+6)$ & $1.01(+6)$ & $5.53(+4)$ & $5.53(+4)$ & $5.66(+4)$ \\
\hline $\mathrm{H}_{2} \mathrm{O}_{2}$ & $6.3(+11)$ & $3.57(+10)$ & $7.88(+11)$ & $1.95(+11)$ & $1.62(+10)$ & $2.04(+11)$ & $1.46(+10)$ & $7.17(+9)$ & $1.68(+10)$ \\
\hline $\mathrm{N}_{2}$ & $2.24(+18)$ & $2.24(+18)$ & $2.24(+18)$ & $4.48(+18)$ & $4.46(+18)$ & $4.63(+18)$ & $6.1(+18)$ & $6.1(+18)$ & $6.1(+18)$ \\
\hline NO & $3.03(+14)$ & $3.57(+14)$ & $3.53(+14)$ & $9.27(+13)$ & $1.11(+14)$ & $9.02(+13)$ & $3.86(+12)$ & $4.55(+12)$ & $4.55(+12)$ \\
\hline $\mathrm{NO}_{2}$ & $1.98(+14)$ & $1.22(+14)$ & $1.28(+14)$ & $6.11(+13)$ & $3.89(+13)$ & $3.35(+13)$ & $2.56(+12)$ & $1.6(+12)$ & $1.7(+12)$ \\
\hline $\mathrm{NO}_{3}$ & $6.14(+10)$ & $3.53(+10)$ & $2.36(+10)$ & $2.77(+7)$ & $1.68(+7)$ & $1.9(+7)$ & $7.34(+7)$ & $7.17(+7)$ & $7.16(+7)$ \\
\hline $\mathrm{N}_{2} \mathrm{O}$ & $2.05(+12)$ & $2.2(+12)$ & $2.2(+12)$ & $1.96(+12)$ & $2.01(+12)$ & $1.99(+12)$ & $2.16(+12)$ & $2.16(+12)$ & $2.16(+12)$ \\
\hline $\mathrm{N}_{2} \mathrm{O}_{5}$ & 0 & 0 & 0 & $4.56(+5)$ & $4.43(+5)$ & $5.58(+5)$ & $1.24(+6)$ & $1.24(+6)$ & $1.24(+6)$ \\
\hline $\mathrm{HNO}$ & $6.55(+3)$ & $7.08(+4)$ & $3.56(+5)$ & $8.33(-2)$ & $1.04(-1)$ & $6.25(-2)$ & $1.31(-5)$ & $1.55(-5)$ & $1.59(-5)$ \\
\hline $\mathrm{HNO}_{2}$ & $3.91(+12)$ & $5.67(+12)$ & $5.22(+12)$ & $1.29(+12)$ & $1.89(+12)$ & $1.4(+12)$ & $5.39(+10)$ & $7.7(+10)$ & $7.07(+10)$ \\
\hline $\mathrm{HNO}_{3}$ & $2.39(+9)$ & $1.37(+9)$ & $1.45(+9)$ & $1.85(+9)$ & $1.53(+9)$ & $1.57(+9)$ & $1.7(+9)$ & $1.68(+9)$ & $1.68(+9)$ \\
\hline $\mathrm{CO}$ & $1.56(+12)$ & $1.57(+12)$ & $1.57(+12)$ & $1.56(+12)$ & $1.57(+12)$ & $1.56(+12)$ & $1.76(+12)$ & $1.76(+12)$ & $1.76(+12)$ \\
\hline $\mathrm{CO}_{2}$ & $9.22(+16)$ & $9.12(+16)$ & $9.11(+16)$ & $2.98(+16)$ & $3.01(+16)$ & $2.5(+16)$ & $3.53(+15)$ & $3.52(+15)$ & $3.53(+15)$ \\
\hline $\mathrm{SO}_{2}$ & $1.35(+10)$ & $1.47(+13)$ & $1.12(+14)$ & $2.36(+10)$ & $4.61(+12)$ & $2.87(+13)$ & $3.14(+10)$ & $2.19(+11)$ & $1.48(+12)$ \\
\hline $\mathrm{SO}_{3}$ & $9.97(+8)$ & $1.18(+12)$ & $7.85(+12)$ & $4.15(+4)$ & $5.19(+7)$ & $1.86(+8)$ & $9.15(+3)$ & $9.93(+4)$ & $6.98(+5)$ \\
\hline $\mathrm{H}_{3} \mathrm{O}^{+}\left(\mathrm{H}_{2} \mathrm{O}\right)$ & $2.58(+4)$ & $9.67(+4)$ & $4.78(+5)$ & $8.68(-6)$ & $9.29(-6)$ & $7.31(-6)$ & $8.17(-7)$ & $8.18(-7)$ & $8.23(-7)$ \\
\hline $\mathrm{H}_{3} \mathrm{O}^{+}\left(\mathrm{H}_{2} \mathrm{O}\right)_{2}$ & $4.69(+4)$ & $1.75(+5)$ & $8.67(+5)$ & $1.63(-1)$ & $6.81(-1)$ & $7.55(-1)$ & $6.51(-6)$ & $7.02(-6)$ & $9.45(-6)$ \\
\hline $\mathrm{H}_{3} \mathrm{O}^{+}\left(\mathrm{H}_{2} \mathrm{O}\right)_{3}$ & $9.4(+2)$ & $3.51(+3)$ & $1.74(+4)$ & $7.68(+2)$ & $2.91(+3)$ & $7.56(+3)$ & 4.16 & 7.23 & $2.19(+1)$ \\
\hline $\mathrm{H}_{3} \mathrm{O}^{+}\left(\mathrm{H}_{2} \mathrm{O}\right)_{4}$ & 2.9 & $1.08(+1)$ & $5.35(+1)$ & $8.97(+3)$ & $3.2(+4)$ & $1.42(+5)$ & $3.1(+3)$ & $5.38(+3)$ & $1.63(+4)$ \\
\hline $\mathrm{H}_{3} \mathrm{O}^{+}\left(\mathrm{H}_{2} \mathrm{O}\right)_{5}$ & $1.24(+1)$ & $4.63(+1)$ & $2.29(+2)$ & $1.19(+4)$ & $4.34(+4)$ & $1.58(+5)$ & $2.21(+2)$ & $3.82(+2)$ & $1.17(+3)$ \\
\hline $\mathrm{H}_{3} \mathrm{O}^{+}\left(\mathrm{H}_{2} \mathrm{O}\right)_{6}$ & 8.06 & $2.99(+1)$ & $1.48(+2)$ & $2.4(+3)$ & $8.87(+3)$ & $2.65(+4)$ & 2.37 & 4.1 & $1.26(+1)$ \\
\hline $\mathrm{H}_{3} \mathrm{O}^{+}\left(\mathrm{CH}_{2} \mathrm{O}\right)$ & $3.06(-1)$ & 0 & $2.02(-8)$ & 1.54 & $6.52(-1)$ & 2.61 & $6.41(-2)$ & $2.66(-2)$ & $1.32(-1)$ \\
\hline $\mathrm{H}_{3} \mathrm{O}^{+}\left(\mathrm{CH}_{2} \mathrm{O}\right)\left(\mathrm{H}_{2} \mathrm{O}\right)$ & $8.18(-7)$ & 0 & 0 & $4.0(-10)$ & $1.63(-9)$ & $2.27(-9)$ & 0 & 0 & 0 \\
\hline $\mathrm{H}_{3} \mathrm{O}^{+}\left(\mathrm{CH}_{2} \mathrm{O}\right)\left(\mathrm{H}_{2} \mathrm{O}\right)_{2}$ & $2.71(-1)$ & 0 & $1.79(-8)$ & $2.09(+1)$ & $6.94(+1)$ & $2.87(+2)$ & 1.56 & 4.54 & $2.06(+1)$ \\
\hline $\mathrm{H}_{3} \mathrm{O}^{+}\left(\mathrm{CH}_{2} \mathrm{O}\right)\left(\mathrm{H}_{2} \mathrm{O}\right)_{3}$ & $6.76(-3)$ & 0 & $4.03(-10)$ & $1.62(+1)$ & $5.84(+1)$ & $2.43(+2)$ & 1.36 & 4.09 & $1.84(+1)$ \\
\hline $\mathrm{NO}_{2}^{-}$ & $1.15(+4)$ & $1.99(+1)$ & $8.63(-1)$ & $5.87(+1)$ & $1.22(-1)$ & $1.74(-3)$ & $1.32(-2)$ & $7.47(-4)$ & $4.42(-5)$ \\
\hline $\mathrm{NO}_{3}^{-}$ & $4.58(+1)$ & $1.16(-2)$ & $2.19(-5)$ & $2.58(+1)$ & $4.58(-4)$ & $4.82(-5)$ & $4.58(-1)$ & $2.22(-2)$ & $1.31(-3)$ \\
\hline $\mathrm{NO}_{3}^{-}\left(\mathrm{H}_{2} \mathrm{O}\right)$ & $2.35(+4)$ & 5.96 & $1.03(-2)$ & $4.11(+3)$ & $7.41(-2)$ & $6.38(-3)$ & 3.91 & $1.89(-1)$ & $1.13(-2)$ \\
\hline $\mathrm{NO}_{3}{ }^{-}\left(\mathrm{HNO}_{3}\right)$ & $5.29(-2)$ & $5.6(-5)$ & $2.36(-7)$ & 2.55 & $2.35(-1)$ & $2.42(-1)$ & 8.2 & 1.45 & $4.64(-1)$ \\
\hline $\mathrm{NO}_{3}{ }^{-}\left(\mathrm{HNO}_{3}\right)_{2}$ & $1.49(-7)$ & $9.32(-11)$ & 0 & 1.89 & $8.43(-1)$ & 1.12 & $2.53(+2)$ & $2.53(+1)$ & 3.6 \\
\hline $\mathrm{NO}_{3}{ }^{-}\left(\mathrm{HNO}_{3}\right)_{3}$ & 0 & 0 & 0 & $6.27(-7)$ & $2.12(-7)$ & $6.54(-7)$ & $2.01(-1)$ & $1.99(-2)$ & $2.8(-3)$ \\
\hline $\mathrm{NO}_{3}{ }^{-}\left(\mathrm{HNO}_{3}\right)_{4}$ & 0 & 0 & 0 & 0 & 0 & 0 & $4.35(-7)$ & $4.24(-8)$ & $5.94(-9)$ \\
\hline $\mathrm{NO}_{3}^{-}\left(\mathrm{HNO}_{3}\right)_{5}$ & 0 & 0 & 0 & 0 & 0 & 0 & 0 & 0 & 0 \\
\hline $\mathrm{NO}_{3}{ }^{-}\left(\mathrm{HNO}_{3}\right)\left(\mathrm{H}_{2} \mathrm{O}\right)$ & $3.03(+2)$ & $3.3(-1)$ & $1.39(-3)$ & $4.56(+3)$ & $4.28(+2)$ & $3.62(+2)$ & $7.86(+2)$ & $1.39(+2)$ & $4.49(+1)$ \\
\hline $\mathrm{SO}_{3}^{-}$ & $3.71(+1)$ & $2.82(+2)$ & $5.55(+1)$ & 9.76 & $8.03(+1)$ & $1.27(+1)$ & $2.24(-1)$ & 1.84 & $3.66(-1)$ \\
\hline $\mathrm{HSO}_{4}^{-}$ & $1.92(+4)$ & $3.66(-4)$ & $8.73(-7)$ & $1.51(-1)$ & $7.16(-6)$ & $7.38(-7)$ & $3.25(-3)$ & $2.96(-4)$ & $1.68(-5)$ \\
\hline $\mathrm{HSO}_{4}^{-}\left(\mathrm{H}_{2} \mathrm{O}\right)$ & $6.87(+1)$ & $1.87(+2)$ & 6.61 & $2.58(+3)$ & $7.77(+1)$ & 6.05 & $1.17(+2)$ & $1.14(+1)$ & 3.59 \\
\hline $\mathrm{HSO}_{4}^{-}\left(\mathrm{HNO}_{3}\right)$ & $1.32(+4)$ & $3.21(+1)$ & $1.25(-2)$ & $1.79(+3)$ & 1.12 & 1.75 & $8.15(+1)$ & $4.19(+1)$ & 9.41 \\
\hline $\mathrm{HSO}_{4}^{-}\left(\mathrm{HNO}_{3}\right)_{2}$ & $2.11(+3)$ & $4.71(+1)$ & 5.31 & $6.85(+3)$ & 6.23 & $4.53(+1)$ & $2.77(+2)$ & $1.54(+2)$ & $4.8(+1)$ \\
\hline $\mathrm{HSO}_{4}^{-}\left(\mathrm{H}_{2} \mathrm{SO}_{4}\right)$ & $3.41(+3)$ & 7.59 & $1.64(-2)$ & $2.47(+1)$ & $1.0(-2)$ & $1.51(-2)$ & $2.76(+1)$ & $2.76(-1)$ & $6.19(-2)$ \\
\hline $\mathrm{HSO}_{4}^{-}\left(\mathrm{H}_{2} \mathrm{SO}_{4}\right)_{2}$ & $8.27(+1)$ & 8.03 & $2.33(-1)$ & $4.3(+2)$ & $7.21(-1)$ & $1.84(-1)$ & $4.8(+2)$ & 1.17 & $2.46(-1)$ \\
\hline $\mathrm{HSO}_{4}^{-}\left(\mathrm{H}_{2} \mathrm{SO}_{4}\right)_{3}$ & 1.29 & $2.75(+5)$ & $1.36(+6)$ & $3.57(+3)$ & $8.66(+4)$ & $3.34(+5)$ & $1.29(+3)$ & $5.41(+3)$ & $1.74(+4)$ \\
\hline $\mathrm{HSO}_{4}^{-}\left(\mathrm{SO}_{3}\right)$ & $1.63(+1)$ & $3.99(+2)$ & $9.21(-1)$ & $7.83(+1)$ & $9.15(-5)$ & $9.67(-5)$ & 3.16 & $1.49(-4)$ & $3.85(-5)$ \\
\hline
\end{tabular}


at $\mathrm{FSC}=0 \%\left(2 \times 10^{4} \mathrm{~cm}^{-3}\right.$ at $40 \mathrm{~m}$ distance from the nozzle exit) indicates that such aerosol particles with $d \sim 5 \mathrm{~nm}$ form (even for free sulfur fuel) because of burning sulfur containing air molecules.

\section{Summary and conclusions}

The effect of sulfur containing species on the formation of volatile aerosols is simulated in this study with a model, which covers the combined dynamics and kinetics of gaseous and ion species in the aircraft engine between the combustor and engine exits and in the young exhaust plume up to about $1 \mathrm{~km}$ behind a B-747 aircraft at cruise. The results are compared to measurements as far as available.

The numerical analysis has shown that $\mathrm{SO}_{3}, \mathrm{HSO}_{3}$, and $\mathrm{H}_{2} \mathrm{SO}_{4}$ form besides $\mathrm{SO}_{2}$ in the combustor and in the turbine and nozzle flow of a jet engine (gas turbine engine). The condensable sulfuric gases significantly affect the aerosol particle size distribution and increase the number of larger size volatile sulfate particles compared to the case when only $\mathrm{SO}_{2}$ is abundant in the engine exhaust. For high fuel sulfur content (FSC $=0.3 \%$ ), the concentration of sulfate aerosols particles with $d>5 \mathrm{~nm}$ reach $10^{8} \mathrm{~cm}^{-3}$ and the concentration of particles with $d>9 \mathrm{~nm}$ are as large as $5 \times 10^{4} \mathrm{~cm}^{-3}$ in the modeled plume of the aircraft. Without $\mathrm{SO}_{3}, \mathrm{HSO}_{3}$ and $\mathrm{H}_{2} \mathrm{SO}_{4}$ species formation inside the engine, the concentration of sulfate aerosols with $d>5 \mathrm{~nm}$ is a factor of 100 smaller, and larger volatile particles with $d>9 \mathrm{~nm}$ are totally absent in this case. The ratio of gaseous to total sulfuric acid, $\xi$, for high fuel sulfur content $(\mathrm{FSC}=0.3 \%)$ drops from 1 at the nozzle exit by up to a factor of $10^{4}$ with plume age increasing up to $1 \mathrm{~s}$. For sulfur free fuel (FSC $=0 \%$ ) the reduction of $\xi$ is only a factor of 10 because of slower kinetics. Only a small fraction of $\mathrm{SO}_{2}$ gets oxidized to $\mathrm{H}_{2} \mathrm{SO}_{4}$ in the plume after the engine exit. Most of the gaseous sulfuric acid gets converted to liquid aerosols within $1 \mathrm{~s}$. This explains why no gaseous sulfuric acid was detectable in previous measurements at plume ages larger $2 \mathrm{~s}$. The abundance of S-containing species, mostly $\mathrm{SO}_{2}, \mathrm{H}_{2} \mathrm{~S}$, and COS, in the ambient air leads to formation of $\mathrm{SO}_{3}$ and $\mathrm{H}_{2} \mathrm{SO}_{4}$ inside the engine and results in generation of small sulfate aerosol particles with $d \leq 1.2 \mathrm{~nm}$ in the plume even for sulfur free fuel $(\mathrm{FSC}=0 \%)$. The computed values of concentrations of large-size sulfate aerosols depends strongly on the method used for calculation of the evolution of combustion products inside the turbine and the nozzle and, as a consequence, on the value of sulfur conversion inside the engine. The model calculations have demonstrated that the presence of $\mathrm{NO}_{3}{ }^{-}, \mathrm{HSO}_{4}{ }^{-}, \mathrm{NO}^{+}$, and $\mathrm{H}_{3} \mathrm{O}^{+}$ions in the engine exhaust results in the fast production of ion clusters in the aircraft plume including negative $\mathrm{HSO}_{4}{ }^{-}\left(\mathrm{H}_{2} \mathrm{SO}_{4}\right)_{m}, \mathrm{HSO}_{4}{ }^{-}\left(\mathrm{HNO}_{3}\right)_{n}$, $\mathrm{NO}_{3}{ }^{-}\left(\mathrm{HNO}_{3}\right)\left(\mathrm{H}_{2} \mathrm{O}\right), \mathrm{HSO}_{4}{ }^{-}\left(\mathrm{SO}_{3}\right)$ and positive $\mathrm{H}_{3} \mathrm{O}^{+}\left(\mathrm{H}_{2} \mathrm{O}\right)_{m}$ or $\mathrm{H}_{3} \mathrm{O}^{+}\left(\mathrm{CH}_{2} \mathrm{O}\right)\left(\mathrm{H}_{2} \mathrm{O}\right)_{m}$ ion clusters. The concentration of $\mathrm{HSO}_{4}{ }^{-}\left(\mathrm{HSO}_{4}\right)_{m}$ and $\mathrm{H}_{3} \mathrm{O}^{+}\left(\mathrm{H}_{2} \mathrm{O}\right)_{m}$ or $\mathrm{H}_{3} \mathrm{O}^{+}\left(\mathrm{CH}_{2} \mathrm{O}\right)\left(\mathrm{H}_{2} \mathrm{O}\right)_{m}$ clusters reaches $\sim 1.4 \times 10^{6} \mathrm{~cm}^{-3}$ at a distance of $10 \mathrm{~m}$ and $1.5 \times 10^{5} \mathrm{~cm}^{-3}$ at $50 \mathrm{~m}$ from the nozzle exit. The abundance of $\mathrm{H}_{3} \mathrm{O}^{+}\left(\mathrm{H}_{2} \mathrm{O}\right)_{m}$ ion clusters in the plume may lead to the formation of ion clusters $\mathrm{H}^{+} \mathrm{X}\left(\mathrm{H}_{2} \mathrm{O}\right)_{n}$ containing hydrocarbon molecules due to ion-molecular reactions of $\mathrm{H}_{3} \mathrm{O}^{+}\left(\mathrm{H}_{2} \mathrm{O}\right)_{m}$ with hydrocarbon molecules possessing large proton affinities and which may be emitted by the engine, mostly $\mathrm{CH}_{2} \mathrm{O}$, $\mathrm{CH}_{3} \mathrm{OH}, \mathrm{C}_{2} \mathrm{H}_{4}$ and $\mathrm{C}_{2} \mathrm{H}_{6}$. Other ions that may be present in the near field plume and potentially affect the volatile aerosol particle formation are heavy hydrocarbon ions, which are expected to form in the fuel-rich zone of the aero-engine combustor.

The charged clusters formed in the plume can potentially enhance the formation of large volatile aerosol particles, induce charges on the surface of soot particles and thus stimulate the uptake of polar water or sulfuric acid molecules by soot particles.
Numerous reactions are considered in this work and a detailed analysis of the errors resulting from uncertainties in the kinetic rate coefficients has still to be made. The computed aerosol properties agree with the observations in terms of trends with FSC and plume age, but the computed concentrations of large aerosol particles are smaller than observed for similar conditions. Improvements are needed in the modeling of a diffusion mode of combustion in the aero-engine and in the ion formation processes, in particular, with respect to the formation of heavy hydrocarbon ions. Corresponding experimental studies are also strongly needed.

\section{Acknowledgements}

This work was performed within the INTAS-2000-00-460 project, CRDF-RC1-2327-MO-02, supported by the Fund for Assistance to Small Innovative Enterprises (project 47M2001) and by the grant of the President of the Russian Federation No. NSh-1574.2003.1.

\section{References}

1 U. Schumann, Ann. Geophys., 1994, 12, 365-384.

2 G. P. Brasseur, R. A. Cox, D. Hauglustaine, I. Isaksen, J. Lelieveld, D. H. Lister, R. Sausen, U. Schumann, A. Wahner and P. Wiesen, Atmos. Environ., 1998, 32, 2329-2418.

3 O. B. Toon and R. C. Miake-Lye, Geophys. Res. Lett., 1998, 25 1109-1112.

4 D. W. Fahey, U. Schumann, S. Ackerman, P. Artaxo, O. Boucher, M. Y. Danilin, B. Kärcher, P. Minnis, T. Nakajima and O. B. Toon, in Aviation and the Global Atmosphere, A Special Report of IPCC (Intergovernmental Panel on Climate Change), ed. J. E. Penner, D. H. Lister, D. J. Griggs, D. J. Dokken and M. McFarland, Cambridge University Press, Cambridge, UK, 1999, pp. $65-120$.

5 R. C. Brown, R. C. Miake-Lye, M. R. Anderson, C. E. Kolb and T. J. Resch, J. Geophys. Res., [Atmos.], 1996, 101, 22 939-22953.

6 B. Kärcher, Geophys. Res. Lett., 1996, 23, 1933-1936.

7 B. Kärcher, R. Busen, A. Petzold, F. P. Schröder, U. Schumann and E. J. Jensen, J. Geophys. Res., [Atmos.], 1998, 103, 17129 17148.

8 F. P. Schröder, B. Kärcher, A. Petzold, R. Baumann, R. Busen, C. Hoell and U. Schumann, Geophys. Res. Lett., 1998, 25, 2789-2792.

9 F. Yu, R. P. Turco, B. Kärcher and F. P. Schröder, Geophys. Res. Lett., 1998, 25, 3839-3842.

10 G. Gleitsmann and R. Zellner, J. Geophys. Res., [Atmos.], 1998, 103, $19543-19556$

11 C. Andronache and W. L. Chameides, J. Geophys. Res., [Atmos.], 1998, 103, $10787-10802$.

12 F. Arnold, T. Stilp, R. Busen and U. Schumann, Atmos. Environ., 1998, 32, 3073-3077.

13 F. Arnold, K.-H. Wohlfrom, M. W. Klemm, J. Schneider, K. Gollinger, U. Schumann and R. Busen, Geophys. Res. Lett., 1998, 25, 2137-2140.

14 F. Arnold, J. Curtius, B. Sierau, V. Bürger, R. Busen and U. Schumann, Geophys. Res. Lett., 1999, 26, 1577-1580.

15 F. Arnold, A. Kiendler, V. Wiedemer, S. Aberle, T. Stilp and R. Busen, Geophys. Res. Lett., 2000, 27, 1723-1726.

16 F. Yu and R. P. Turco, J. Geophys. Res., [Atmos.], 1998, 103, 25915-25934.

17 U. Schumann, J. Ström, R. Busen, R. Baumann, K. Gierens, M. Krautstrunk, F. P. Schröder and J. Stingl, J. Geophys. Res., [Atmos.], 1996, 101, 6853-6870.

18 F. Schröder, C. A. Brock, R. Baumann, A. Petzold, R. Busen, P. Schulte and M. Fiebig, J. Geophys. Res., [Atmos.], 2000, 105, 19941-19954.

19 U. Schumann, F. Arnold, R. Busen, J. Curtius, B. Kärcher, A. Kiendler, A. Petzold, H. Schlager, F. Schröder and K.-H. Wohlfrom, J. Geophys. Res., [Atmos.], 2002, 107(D15), 4247.

20 J. Curtius, B. Sierau, F. Arnold, R. Baumann, R. Busen, P. Schulte and U. Schumann, Geophys. Res. Lett., 1998, 25, 923-926.

21 R. C. Brown, R. C. Miake-Lye, M. R. Anderson and C. E. Kolb, Geophys. Res. Lett., 1996, 23, 3607-3610.

22 F. Yu and R. P. Turco, Geophys. Res. Lett., 1999, 26, 1703-1706. 
23 A. M. Starik, A. M. Savel'ev and N. S. Titova, J. Aerosol Sci., 2000, 31(Suppl. 1), 382-383.

24 A. M. Starik, A. M. Savel'ev, N. S. Titova and U. Schumann, Aerosp. Sci. Technol., 2002, 6, 63-81.

25 V. E. Kozlov, A. N. Secundov and I. P. Smirnova, Fluid Mech.Sov. Res., 1988, 17, 93-102.

26 A. B. Lebedev, A. M. Starik and N. S. Titova, High Temp. (Transl. Teplofiz. Vys. Temp.), 1998, 36, 75-89.

27 L. I. Zaichik, A. B. Lebedev, A. M. Savel'ev and A. M. Starik, High Temp. (Transl. Teplofiz. Vys. Temp.), 2000, 38, 77-86.

28 A. Luts, Mathematical Simulation of the Evolution of Air Ions, Dissertationes Geophysicales Universitatis Tartuensis, Tartu University, 1995, .

29 E. R. Lovejoy, D. R. Hanson and L. G. Huey, J. Phys. Chem., 1996, 100, 19911-19916.

30 J. T. Jayne, U. Pöschl, Y. Chen, D. Dai, L. T. Molina, D. R. Worsnop, C. E. Kolb and M. J. Molina, J. Phys. Chem. A, 1997, 101, $10000-10011$.

31 J. C. Person and D. O. Ham, Radiat. Phys. Chem., 1988, 31, 1-8.

32 H. Kawamoto and T. Ogawa, Planet. Space Sci., 1984, 32, 1223-1233.

33 I. A. Kossyi, A. Yu. Kostinsky, A. A. Matveyev and V. P. Silakov, Plasma Sources Sci. Technol., 1992, 1, 207-220.

34 A. A. Viggiano, J. V. Seeley, P. L. Mundis, J. S. Williamson and R. A. Morris, J. Phys. Chem. A, 1997, 101, 8275-8278.
35 A. J. Midey, S. T. Arnold and A. A. Viggiano, J. Phys. Chem., 2000, 104, 2706-2709.

36 G. G. Chernyi, S. A. Losev, S. O. Macheret and B. V. Potapkin, Prog. Astronaut. Aeronaut., 2002, 196, 325p.

37 F. Yu, R. P. Turco and B. Kärcher, J. Geophys. Res., [Atmos.] 1999, 104, 4079-4088.

38 A. Kiendler, S. Aberle and F. Arnold, Atmos. Environ., 2000, 34, 4787-4793.

39 A. M. Savel'ev, A. M. Starik and N. S. Titova, High Temp. (Transl. Teplofiz. Vys. Temp.), 1999, 37, 470-478.

40 U. Schumann, H. Schlager, F. Arnold, R. Baumann, P. Haschberger and O. Klemm, Atmos. Environ., 1998, 32, 3097-3103.

41 B. Kärcher, J. Geophys. Res., [Atmos.], 1998, 103, 17 111-17 128.

42 B. Kärcher and D. W. Fahey, Geophys. Res. Lett., 1997, 24, 389-392.

43 S. P. Lukachko, I. A. Waitz, R. C. Miake-Lye, R. C. Brown and M. R. Anderson, J. Geophys. Res., [Atmos.], 1998, 103, $16159-16174$.

44 B. Kärcher, F. Yu, F. P. Schröder and R. P. Turco, Geophys. Res. Lett., 1998, 25, 2793-2796.

45 A. Petzold, J. Ström, F. P. Schröder and B. Kärcher, Atmos. Environ., 1999, 33, 2689-2698.

46 H. G. Tremmel and U. Schumann, Aerosp. Sci. Technol., 1999 , 3, 417-430. 